$1-1-1967$

\title{
Management and productivity of perennial grasses in the Northeast.
}

\author{
A. M. Decker
}

Follow this and additional works at: https://researchrepository.wvu.edu/ wv_agricultural_and_forestry_experiment_station_bulletins

\section{Digital Commons Citation}

Decker, A. M., "Management and productivity of perennial grasses in the Northeast." (1967). West Virginia Agricultural and Forestry Experiment Station Bulletins. 550T.

https://researchrepository.wvu.edu/wv_agricultural_and_forestry_experiment_station_bulletins/670 @ WVU. It has been accepted for inclusion in West Virginia Agricultural and Forestry Experiment Station Bulletins by an authorized administrator of The Research Repository @ WVU. For more information, please contact ian.harmon@mail.wvu.edu. 


\section{Digitized by the Internet Archive in 2010 with funding from Lyrasis Members and Sloan Foundation}


MANAGEMENT and PRODUCTIVITY of PERENNIAL GRASSES in the NORTHEAST I. REED CANARYGRASS

West Virginia University Agricultural Experiment Station

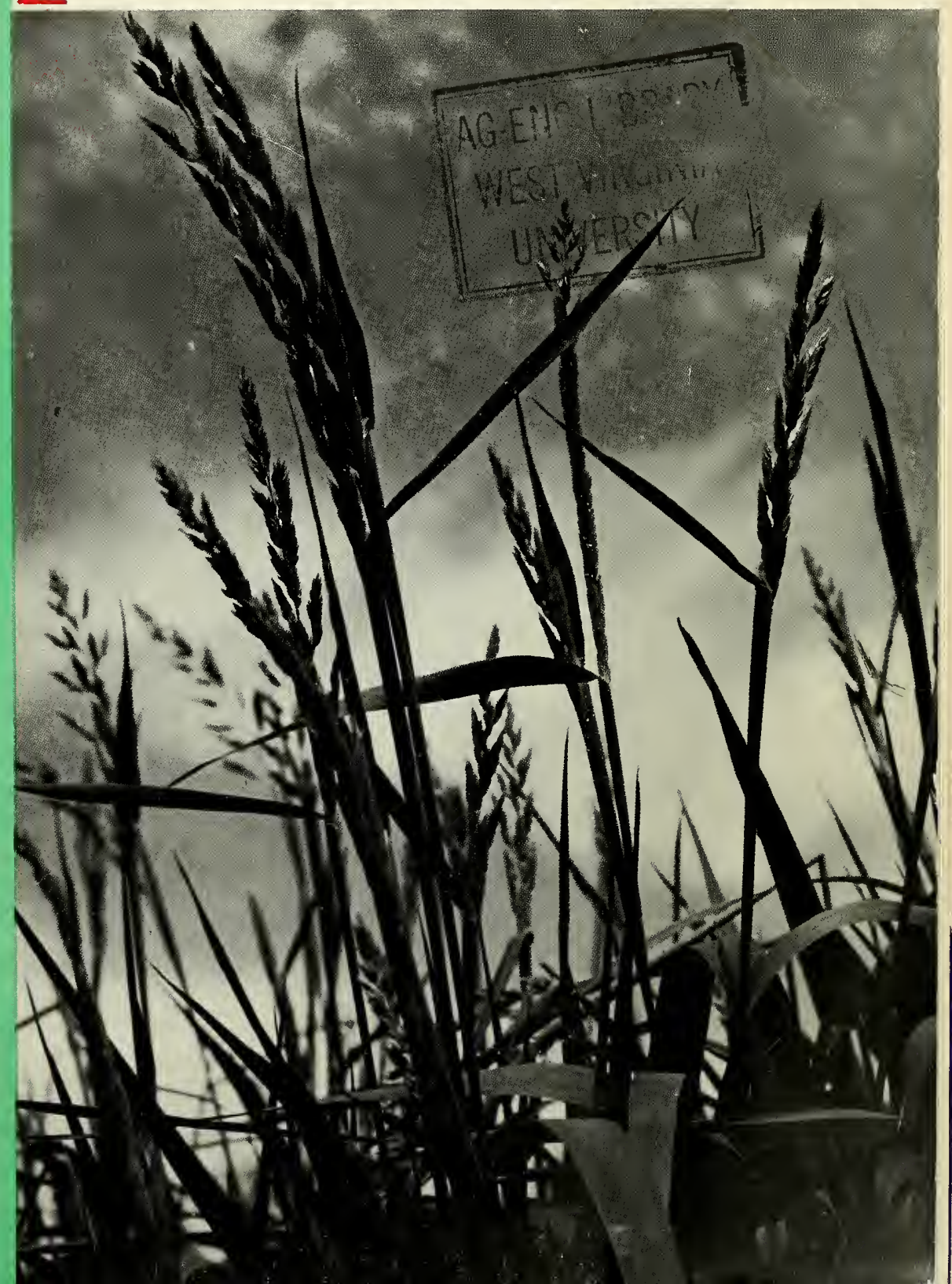





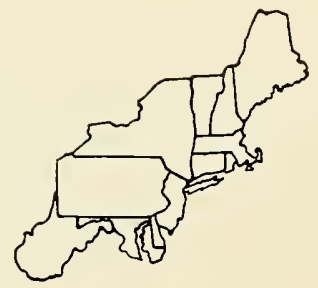

\title{
Management and Productivity of Perennial Grasses in the Northeast: I. Reed Canarygrass
}

\author{
A. M. Decker, G. A. Jung, J. B. Washko, D. D. Wolf, and M. J. Wright
}

REGIONAL FORAGE CROP MANAGEMENT TECHNICAL COMMITTEE (NE-29)

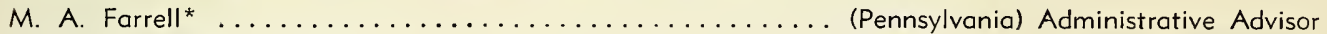

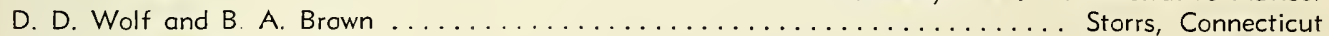

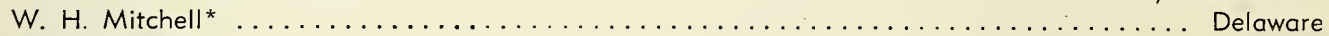

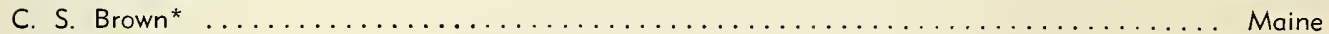

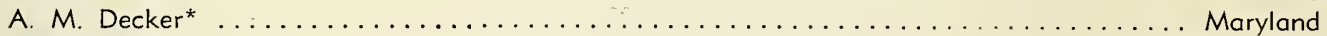

W. G. Colby ${ }^{*} \ldots \ldots \ldots \ldots \ldots \ldots \ldots \ldots \ldots \ldots \ldots \ldots \ldots \ldots \ldots \ldots \ldots \ldots \ldots \ldots \ldots \ldots$ Massachusetts

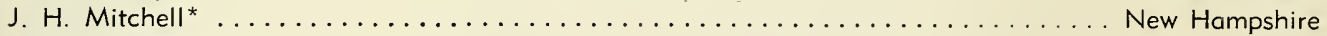

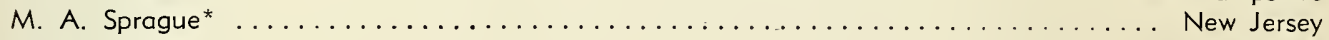

M. J. Wright ${ }^{\star} \ldots \ldots \ldots \ldots \ldots \ldots \ldots \ldots \ldots \ldots \ldots \ldots \ldots \ldots \ldots \ldots \ldots \ldots \ldots \ldots \ldots$ New York

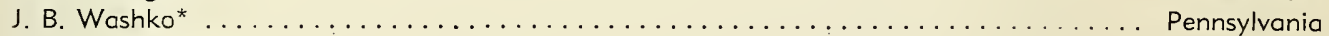

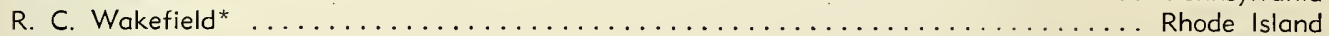

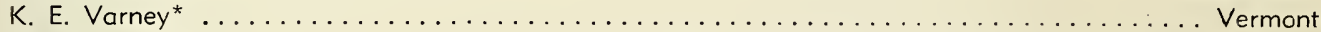

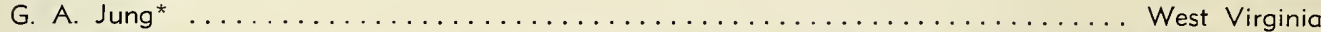

V. G. Sprague* ... . . . . . . . . U.S.D.A. Research Service, U.S. Regional Pasture Research Lab.

G. E. Carlson*, D. E. McCloud, \& H. O. Graumann .. U.S.D.A. Research Service, Crops Research Division

H. J. Hodgson*, T. S. Ronningen, \& N. F. Farris . . U.S.D.A. Cooperative State Experiment Station Service

- Current official representatives.

\section{West Virginia University \\ Agricultural Experiment Station}

A. H. VanLandingham, Director 


\section{Contents}

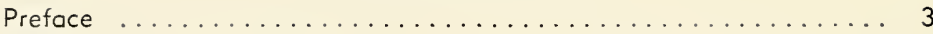

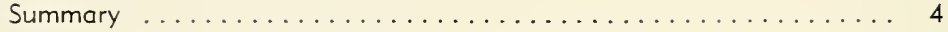

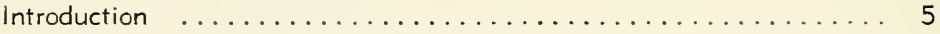

Literature Review ...................... 6

Stage of Maturity at First Harvest ............... 6

Nitrogen Fertilization $\ldots \ldots \ldots \ldots \ldots \ldots \ldots \ldots \ldots \ldots$

Height and Frequency of Clipping $\ldots \ldots \ldots \ldots \ldots \ldots \ldots$

Carbohydrate Reserves .................... 7

Nutritive value ..................... 8

Materials and Methods ...................... 9

Experimental Results ..................... 11

Yields Produced in the First Year After Seeding (1960) ... . . . 11

Yields Produced in the Second Harvest Year (1961) . . . . . . . 13

Yields Produced in the Third Year (1962) ............ 15

Aftermath Production in the First Year $(1960) \ldots \ldots \ldots$

Aftermath Production in the Second Year (1961) ......... 16

Aftermath Production in the Third Year (1962) ......... 17

Regrowth Potential . . . . . . . . . . . . . . . 17

Carbohydrate Reserves .................... 22

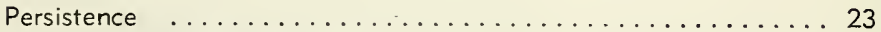

Residual Treatment Effects . . . . . . . . . . . . . . 25

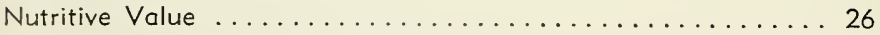

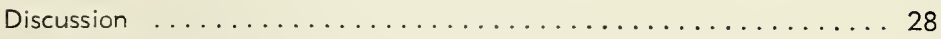

Literature Cited ........................ 33

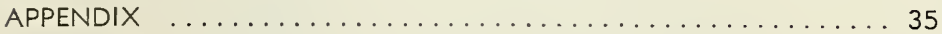




\section{Preface}

This publication describes experiments conducted by several experiment stations in the Northeastern Region of the United States, under the auspices of Northeastern Regional Technical Committee NE-29. A. M. Decker, Maryland Agricultural Experiment Station; J. B. Washko, Pennsylvania Agricultural Experiment Station; D. D. Wolf, Connecticut, Storrs, Agricultural Experiment Station; and M. J. Wright, New York, Cornell University Agricultural Experiment Station were responsible for the collection, statistical analyses, and interpretation of data. A manuscript was then prepared from these station summaries by A. M. Decker. Preparation and organization of the final manuscript was the responsibility of G. A. Jung, West Virginia Agricultural Experiment Station.

The authors gratefully acknowledge the contributions of Prof. B. A. Brown, Connecticut, Storrs, Agricultural Experiment Station, and Drs. W. K. Kennedy and M. R. Teel, New York, Cornell University Agricultural Experiment Station, who assisted with the planning of the experiments; of Dr. V. G. Sprague, U. S. Regional Pasture Research Laboratory, who assembled the weather data; and of Dr. R. L. Reid, West Virginia Agricultural Experiment Station, who performed nutritive evaluations. 


\section{SUMMARY}

Experiments were conducted in four Northeastern states to test the effects of harvesting at several stages of growth, fertilizing with nitrogen at two rates, and cutting the aftermath at two heights on yield, persistence, and forage quality.

1. These studies clearly demonstrate that reed canarygrass forage production can be high (six tons dry matter/A) with adequate fertilization and favorable cutting management when adequate moisture is available. Nitrogen fertilization, using rates between 100 and 400 pounds of nitrogen per acre, affected yields of dry matter more than did cutting treatments. Total yields of dry matter were generally highest when the first crop was harvested at late growth stages, but little advantage was observed in delaying harvest of the first crop beyond the heading stage.

2. Aftermath yields were generally high when the high rate of nitrogen was applied and when the first crop was cut at the early head or early bloom stage. Aftermath yields were lowest when the low rate of nitrogen was applied and when the first crop was cut at the past bloom stage. In many instances, aftermath production was tripled with high rates of nitrogen fertilization and favorable cutting management.

3. Considerable difference was noted in estimations of plant reserves by an etiolated growth technique and by chemical analyses. Regrowth potential, as indicated by etiolated growth, was not affected in a consistent manner when plants were harvested at different growth stages. Concentrations of carbohydrate reserves in plant organs were lowest in summer and were found to be higher in crowns than in roots and were lowest in stubble.

4. There did not appear to be a close relationship between cutting the first crop at different growth stages and stand persistence. Good stands of reed canarygrass were maintained for three harvest-years, even with adverse climatic conditions. A high rate of fertilization with nitrogen was essential in maintaining productive, vigorous stands.

5. Removing or retaining the growing point when harvesting one aftermath crop had only a small effect on yields or stand persistence. There was, however, a short-time effect of this treatment on plant reserves immediately following cutting.

6. The apparent quality of reed canarygrass forage can be improved by early harvesting and nitrogen fertilization. 


\section{Management and Productivity of Perennial Grasses in the Northeast: I. Reed Canarygrass}

A GRONOMISTS in the Northeast have par$\mathrm{I}_{\text {ticipated in regional forage management re- }}$ search investigations since 1949. These regional research efforts have included studies dealing with species adaptation and production comparisons (38), performance of legumes grown alone and in grass mixtures under different cutting management systems (40), and legume-grass establishment as influenced by fertilizer and managerial treatments $(41,42)$. In each case an attempt was made to relate observed forage plant responses to the wide differences in climate found in the Northeast Region (39). The major emphasis of these research efforts was devoted to legume culture until 1958 when it was decided that attention should be directed toward perennial forage grass culture.

Grasses adapted to the Northeast have almost invariably been sown in mixtures with legumes. Through attrition of the legume stands the grasses eventually assume first importance. While the persistence of grasses has been looked upon as a useful characteristic, the general recommendation has been to renovate older, grass-dominant associations and re-establish legume-grass mixtures. For maximum productivity, grasses are known to require fertilization and management systems substantially different from those needed by legumes. There is reason to believe that successful management of mixtures has included deleterious management of grasses in order to retain legumes.

While the contribution of legumes in grasslegume mixtures has been widely recognized for increasing productivity and quality of forage, farmers now have many reasons for considering the culture of pure stands of grass. Abundant supplies of nitrogenous fertilizers at modest cost have freed the forage crop producer from the obligation of maintaining legumes. Grasses may thus be sown alone, or swards of grasses remaining from grass-legume mixtures may be retained, provided sufficiently productive systems of management can be developed. Furthermore, numerous conditions exist under which legumes can be grown or maintained only with difficulty. Poor soil drainage, untillable sites, winter heaving losses, root and crown rot diseases, and insect injury pose serious obstacles to the maintenance of legume stands in grasslands. Where these conditions are encountered, dependence upon grasses alone may be more rewarding than struggling with legume culture.

It appeared appropriate, therefore, to study the relationships between physiological or morphological plant development and the management of perennial grasses in order to determine practices most conducive to stand maintenance with maximized total and aftermath production of high quality forage. An experiment was designed to study these relationships in common reed canarygrass (Phalaris arundinacea L.), three varieties of orchardgrass (Dactylis glomerata L.), two varieties of bromegrass (Bromus inermis Leyss.), and "Climax" timothy (Phleum pratense L.). The regional data and conclusions for each species have been prepared in a separate bulletin. This particular bulletin deals with results of the reed canarygrass investigations.

Reed canarygrass is a species native to North America and is adapted to much of the northern half of the United States and the southern part of Canada. In the United States, it is grown most extensively in the North Central and North Pacific Coast States. It has been grown on a limited acreage in the Northeastern States for some time. Because of its wide adaptability to soil and climatic conditions, good production, and freedom from the serious foliar diseases that occur on many grasses in the Northeast, it was included in a regional management experiment started in 1959. Stands of reed canarygrass at Storrs, Connecticut; C olle g e Park, Maryland; Ithaca, New York; and Centre Hall, Pennsylvania were subjected to nearly identical management for three years. 


\section{LITERATURE REVIEW}

Reed canarygrass (Phalaris arundinacea L.) is a perennial, cool-season grass that is well adapted to poorly drained soils, tolerating flooding for more than a month. It begins growth early in spring and may reach a height of 6 feet or more when fully headed. The stems of reed canarygrass are stout and resist lodging. Mature elongated culms have from 7 to 9 leaves below the inflorescence (23). It grows well on most soils and will tolerate a pH range of 4.9 to 8.2. When grown on upland soils, however, reed canarygrass will maintain a highly productive stand only when nitrogen fertilization is adequate $(5,23,46,47,52,61,64)$. Non-heading aftermath growth continues to provide pasture in midsummer except during severe drought and remains productive until frost. Elongation of the aftermath internodes does not occur unless the day length is greater than 12 to 13 hours (10) and culms often develop branches from aboveground nodes late in the season (23). Agronomic characteristics for individual spaced plants have been observed to vary greatly. For example, under Iowa conditions (7) leafiness varied from 18 to 47 per cent, leaf width varied from 9 to 25 $\mathrm{mm}$ and date of bloom ranged from June 1 to
16. These responses may be modified in solid stands because the authors reported low correlations between the vigor or yield ratings obtained in spaced plantings and those obtained in solid stands.

Reed canarygrass has thick rhizomes, usually pink, which are generally found at depths of 1 to 3 inches below the soil surface and form a tough sod that can support heavy traffic in poorly drained areas. Evans and Ely (23), in a study of tiller emergence, found that 22 per cent of the rhizome tips curved upwards in samples taken in July and that by November the proportion had increased to 56 per cent.

Although reed canarygrass is normally winter hardy within the United States, early spring top growth seems to be more susceptible to injury from late spring frosts than are shoots of several hardy forage grasses such as smooth bromegrass and timothy $(5,23)$.

Reed canarygrass has been relatively free from attack by insects or disease. However, frit fly infestation in the Northeastern United States was found to destroy the growing point (65). The grass is a moderately strong competitor to weeds other than quackgrass (33).

\section{Stage of Maturity at First hiarvest}

Reed canarygrass clipped at early growth stages produced forage of better quality and was followed by a larger second crop than when the first crop was harvested at late growth stages, but clipping at earlier growth stages yielded considerably less dry matter per cutting and per season (33). It is generally recognized from studies with many grasses, that the amount of dry matter, percentages of nitrogenfree extract, crude fiber, cellulose, and lignin increase with advancing maturity while percentages of moisture, protein and ether extract decrease $(2,4,5,11,17,22,25,28,33,45,52)$.

\section{Nitrogen Fertilization}

It has been found that reed canarygrass responds to high levels of soil fertility. Ramage et al. (49), in a three-year trial with reed canarygrass, obtained an average dry matter yield of 4.5 tons per acre per year when using 400 pounds of nitrogen. Each year the nitrogen application was divided into 200-pound increments with one increment applied in March and the other applied after the first harvest. The first harvest was made at the heading stage and two more harvests were made when there were about 3,000 pounds of regrowth dry matter per acre.

Harrington and Washko (29) conducted a one-year high nitrogen fertilization experiment 
at Pennsylvania State University with reed canarygrass, orchardgrass, smooth bromegrass, and timothy. Nitrogen was applied at rates of $0,25,50,100$, or 200 pounds per acre, with comparisons made between nitrogen applied only in spring and nitrogen applied in spring and after each harvest. In terms of both dry matter and protein production per pound of nitrogen used, reed canarygrass used nitrogen most efficiently when the nitrogen was applied in the spring at the 50 pound per acre rate. In general, reed canarygrass and orchardgrass produced the largest dry matter yields, had the highest crude protein content, and yielded the most protein per acre under all nitrogen levels. Forage production over the season was more evenly distributed in those treatments receiving nitrogen after each harvest, but more than 91 per cent of the total production of dry matter and protein was obtained in the first two harvests from most treatments.

Under New Jersey conditions, Duell (21) found that by applying as much as 1,000 pounds of 10-10-10 fertilizer per acre in spring, yields of six grass species were markedly increased in the first two cuttings, but there was little effect on later cuttings. Orchardgrass and Kentucky bluegrass were more responsive to this fertilization than were reed canarygrass and bromegrass. Compared with the other grass species, reed ca- narygrass consistently had high protein and potassium contents.

Nitrogen fertilization was reported to increase the percentage of crude protein in reed canarygrass forage but decrease the percentage of nitrogen-free extract $(2,9,16,49)$. The crude fiber and cellulose of heavily fertilized reed canarygrass hay was found to be more digestible than the same fractions of heavily fertilized alfalfa hay (16). This comparison may not be valid because the reed canarygrass hay was made from the second crop, whereas the alfalfa hay was made from the third crop, but Barth et al. (9) also reported that fibers of reed canarygrass were digested better than those of early-bloom alfalfa, provided the grass was cut at the early boot stage, or was an aftermath growth that had received 100 or 200 pounds of nitrogen per acre. They noted that first cutting reed canarygrass receiving no fertilizer nitrogen had a higher total digestible nutrient content and higher digestibility coefficients for fiber, nitrogen-free extract, energy, and dry matter than second cutting reed canarygrass hays that had received 100 or 200 pounds of nitrogen per acre and were cut six weeks later in the season. It is not clear, however, whether those differences were due to time of cutting or nitrogen fertilization.

\section{Height and Frequency of Clipping}

Clipping experiments with most grasses have shown that the yields of aerial and underground parts are reduced as height of clipping and interval between clippings are reduced $(15$, $27,28,30,62$ ). In a greenhouse experiment with reed canarygrass, Davis (18) measured the rate at which 10 inches of regrowth was produced when plants were clipped at heights of $1,2,3$, 4 , and 5 inches. He found that plants clipped at
4- and 5-inch heights had faster rates of regrowth, more nodal branching and higher yields than plants cut at 1 - and 2-inch heights. According to Teel (57), proper timing of cutting is highly beneficial to bromegrass since a cut that does not remove the shoot apex allows that shoot to continue to develop, whereas a new shoot must be produced to replace an apex that is decapitated.

\section{Carbohydrate Reserves}

Weinmann (63) determined that the principal carbohydrates in roots of reed canarygrass consisted of fructosans and non-reducing sugars, and in rhizomes consisted entirely of fructosans.
The carbohydrate content in the roots was about 6 per cent and that in the rhizomes 36 to 39 per cent of the dry matter. Okajima and Smith (44) reported that under Wisconsin conditions the 
stem bases of Ioreed reed canarygrass sampled at seed maturity contained 1.5 per cent glucose and fructose, 2.7 per cent sucrose, 20.6 per cent fructosan, and 4.5 per cent starch.

Begg and Wright (10) concluded from defoliation studies with reed canarygrass that there was an order of priority for utilization of photosynthate for growth and development of the vegetative shoot. First call for photosynthate was for initiation and development of leaves at the apex. The next priority was for an increase in dry weight of the shoot. Lastly, photosynthate was utilized for build-up of metabolizable root reserves, for which at least five leaves were necessary before there was any appreciable storage.

Nitrogen fertilization of grasses has been shown to diminish storage of carbohydrates (53,
$54,56)$. Several workers have pointed out that this reduction of carbohydrates is not detrimental to plants grown under lenient management. In studies of several perennial forage plants, however, Graber et al. (28) found that any new top growth, especially during the early vegetative growth stages, was initiated and developed largely at the expense of previously accumulated reserves. Furthermore, it was stated that reserves were essential to normal top and root development; that their quantity, quality, and availability sharply limited the amount of both top and root growth which would occur; and that progressive exhaustion of such reserves by early, frequent, and complete removals of top growth resulted ultimately in death of the plant, regardless of climatic conditions.

\section{Nutritive Value}

Although reed canarygrass has been the subject of experiments for 200 years, there is little agreement on its nutritive value. The early investigators, for the most part, equated crude protein content with the nutritive value of the forage. As early as 1856 , research investigations on reed canarygrass in the Northeast were concerned with its protein content. In a Massachusetts study (26) the crude protein content was reported highest in the leaves, intermediate in the joints, and lowest in the stalks. The levels of crude protein reported were low (approximately 4 per cent for all fractions), whereas later studies in Vermont (32) and Massachusetts (55) revealed much higher levels (12 to 15 per cent). In 1926-27 Feldt $(24,25)$, working in Germany, fointed out that several harvests of reed canarygrass per season would result in more valuable forage than if a single harvest were taken. He observed a higher protein content (22 per cent) in forage cut on May 19 than in forage cut on June 9 or 26 (11, 7 per cent); and he also observed a higher protein content in forage cut more frequently. Alway and Nesom (2) compared 36 strains of reed canarygrass and found that the range of crude protein content for whole plants was from 6.6 to 25.2 per cent, with culms having a range of crude protein content from 2.8 to 11.9 per cent, leaves 8.5 to 23.5 per cent, and panicles 9.4 to 30.5 per cent. These differences, however, partly leflect variation in growth stage at the time of harvest and variation in nitrogen fertilization.

Several early reports $(5,33,52)$ stated that reed canarygrass pasture or hay was acceptable to most classes of livestock, but that the forage was not equivalent to alfalfa in nutritive value. These authors recognized the importance of harvesting at an early growth stage. Arny et al. (5) found that when reed canarygrass hay was substituted for alfalfa hay, consumption by dairy cattle dropped from 13 to 14 pounds per day to 5.7 pounds per day. After three weeks, consumption of the reed canarygrass hay rose to 11 pounds per day. Milk production on the average was 3 to $3 \frac{1}{2}$ pounds per day lower for reed canarygrass than for alfalfa. Schoth (52) recommended early grazing to retard the hay making period and to produce leafier forage. He reported reed canarygrass silage to be palatable and nutritious, whereas first harvest hay might be best used fol over-wintering cattle. Vary et al. (60) reported that Michigan farmers believed reed canarygrass would be best utilized if fed alone to animals which were confined since the animals consume other forages if given a choice. The farmers also pointed out that it was important to keep reed canarygrass grazed below 12 inches in height.

Reports that animals grazing reed canarygrass had an unthrifty appearance and low rates of gain resulted in the initiation of a grazing 
experiment in Michigan (59). After three years the researchers confirmed the existence of these problems but were unable to determine the cause of the poor performance. The symptoms were not corrected by mineral, protein, and energy feed supplements, although a few animals grew at near normal rates. All experimental animals made heavy gains and assumed a thrifty appearance when, at the end of the experiment, they were allocated to Kentucky bluegrass or alfalfa-bromegrass pastures.

Phillips et al. (45) concluded in 1954 from chemical determinations of protein, lignin, fiber, cellulose, nitrogen-free extract, fructosan, and soluble ash of eight different grasses harvested at various stages of growth, that grasses having a high quality were reed canarygrass, "Alta" fescue, and Kentucky bluegrass. Grasses having an intermediate feeding value were bromegrass, orchardgrass, and tall oatgrass, whereas species of low quality were timothy and red top. Furthermore, digestibility of reed canarygrass has been found by some researchers to be equal to or higher than that of alfalfa $(3,34,58)$, although two investigators $(1,43)$ have reported its digestibility to be inferior to that of alfalfa. Possible explanations for these contradictions are provided in the research findings of O'Donovan (43), Thomas et al. (58), and Bratzler (12). O'Donovan (43) found that at early growth stages reed canarygrass was more digestible than alfalfa, whereas at later stages of growth, reed canarygrass was equal to alfalfa in digestibility or was less digestible. Studies by Brown (13), Barnes et al. (8), Brown and Pickett (14), Roe and Mottershead (51), O'Donovan (43) and Thomas et al. (58) showed that there are differences in palatability and digestibility among various strains and varieties of reed canarygrass.

Pritchard et al. (48) compared in vitro digestibility of "Climax" timothy, "Frode" orchardgrass, "Lincoln" bromegrass, tall fescue, mountain rye, and "Frontier" reed canarygrass forage with changes in maturity. Under Canadian conditions, bromegrass and reed canarygrass had higher coefficients of digestibility than the other grasses at the flowering stage of growth.
However, decline in digestibility was associated with stage of growth; therefore, early maturing species such as bromegrass and reed canarygrass had lower digestibility coefficients when cut on the same date as the other grasses. They also found that digestibility began to decline most rapidly at head emergence and that rate of decline was greater for heads and stems than for leaves.

Recent nutritive investigations of reed canarygrass indicate the importance of animal intake measurements. In studies with sheep, Thomas et al. (58) found the voluntary intake of dry matter for "Vernal" alfalfa to be 29 to 33 gm per kg body weight, for "Lincoln" bromegrass 28 to $33 \mathrm{gm}$, for common reed canarygrass 25 to $31 \mathrm{gm}$, and for "Siberian" reed canarygrass $20 \mathrm{gm}$ per $\mathrm{kg}$ body weight. Similarly, O'Donovan (43) and Ingalls et al. $(34,35)$ have shown with either ad libitum or preference feed trials that reed canarygrass is among the least acceptable to animals in comparison with other forage species. The complexity and importance of animal preference is further illustrated by the work of Decker (19) who found reed canarygrass-ladino clover pastures to be as productive and as acceptable to grazing animals as orchardgrass-ladino when the legume component was adequate ( 30 to 50 per cent clover). When the percentage of clover was low, however, animal gain per day and beef production per acre were less on the reed canarygrass mixture. This occurred even though more forage was available for grazing in the reed canarygrass pastures. Bratzler (12) has observed decreases in both digestibility and acceptability with an advance in plant maturity. The Nutritive Value Index (intake $\mathrm{x}$ energy digestibility) of forage cut in full bloom was only $2 / 3$ of that cut in the early boot stage of growth (4 weeks earlier).

It is evident from the inconsistencies and shortage of information in the literature that the development of a system of management that will optimize plant response and animal performance must await the gathering of much additional knowledge.

\section{MATERIALS AND METHODS}

The experimental area at each station was located on a well-or moderately well-drained soil of medium to good fertility that had been uni- formly fertilized in previous years. Approximately six months prior to seeding, each area was treated with herbicides to eliminate volun- 
TABLE 1

Site Descriptions and Seeding Dates

\begin{tabular}{|c|c|c|c|c|c|}
\hline Location & $\begin{array}{c}\text { Elevation } \\
\text { (ft.) }\end{array}$ & Latitude & $\begin{array}{c}\text { Growing } \\
\text { Degree Days* }\end{array}$ & Soil Type & Seeding Date \\
\hline $\begin{array}{l}\text { Storrs, } \\
\text { Connecticut }\end{array}$ & 600 & $41^{\circ} 48^{\prime}$ & 3825 & $\begin{array}{l}\text { Paxton Fine } \\
\text { Sandy Loam }\end{array}$ & August 16,1959 \\
\hline $\begin{array}{l}\text { Ithaca, } \\
\text { New York }\end{array}$ & 950 & $42^{\circ} 27^{\prime}$ & 3952 & $\begin{array}{l}\text { Williamson } \\
\text { and Kibbie } \\
\text { Silt Loams }\end{array}$ & April 22-23, 1959 \\
\hline $\begin{array}{l}\text { Centre Hall, } \\
\text { Pennsylvania }\end{array}$ & 1,175 & $40^{\circ} \quad 48^{\prime}$ & 4366 & $\begin{array}{l}\text { Hublersburg } \\
\text { Silt Loam }\end{array}$ & April 23, 1959 \\
\hline $\begin{array}{l}\text { College Park, } \\
\text { Maryland }\end{array}$ & 415 & $38^{\circ} 59^{\prime}$ & 5046 & $\begin{array}{l}\text { Sassafras } \\
\text { Silt Loam }\end{array}$ & August 27,1959 \\
\hline
\end{tabular}

- March 1 to September 26 with base of $40^{\circ} \mathrm{F}$ (20)

teer grasses. The area was limed to raise the soil $\mathrm{pH}$ to at least 6.5. Eighty pounds of $\mathrm{N}, 70$ pounds of $\mathrm{P}$, and 128 pounds of $\mathrm{K}$ were worked into the soil just prior to seeding. The seedings were made at all locations in 1959 (Table 1) using one seed source, and satisfactory stands were obtained at each location. After the grass was established, broadleaf weeds were controlled with 2, 4-D. Uniform applications of 66 pounds of $\mathrm{P}$ and 240 pounds of $\mathrm{K}$ were applied during 1960 , 1961, and 1962 with one-half applied in midsummer and the other each fall after the last harvest.

In the first year "low nitrogen" plots received 15 pounds per acre in early spring, 30 rounds per acre after each of the first two harvests, and 25 pounds per acre after the final fall harvest. The "high nitrogen" rates were 55, 110, and 25 pounds respectively. For the second and third years, the low $\mathrm{N}$ treatments received 25 pounds of nitrogen shortly after growth began and after each harvest throughout the growing season. For the high rate the time of application was the same; but 75 pounds of $\mathrm{N}$ were used except following the final fall harvest, when only 25 pounds were applied.

For the first harvest, one group of plots was uniformly cut to a $2 \frac{1}{2}$-inch stubble when the plants of the high nitrogen treatment were in the pre-joint (PJ) growth stage, most unemerged heads being less than $2 \frac{1}{2}$ inches above the soil surface; a second group was harvested when they reached the early head (EH) growth stage, with heads beginning to emerge on less than 10 per cent of the plants; a third group of plots was cut when plants reached early bloom (EB), anthers visible on less than 10 per cent of the plants; and a fourth group of plots was harvested when the plants were in the past bloom (PB) growth stage, two weeks after early bloom. Dates of first and subsequent harvests at each location are given in Appendix Table 1.

Two stubble heights of cut were imposed at the second harvest of all plots except those cut at the pre-joint growth stage. On these plots, second harvest was at early head and the differential cut was applied at the third harvest. This differential stubble cut was made when the growing points of the aftermath tillers of reed canarygrass on the high nitrogen plots were between 1 and 3 inches above the soil surface. One-

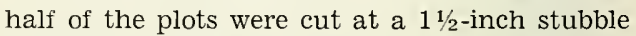
height (to remove most of the active growing points) and one-half were cut at a $3 \frac{1 / 2}{2}$-inch stubble height (to retain most of the active growing points). On harvests conducted after the differential stubble height cut, all plots were harvested at a uniform 21/2-inch stubble height when plants of the high nitrogen plots were at a late joint or retillering stage. Cutting was never delayed longer than six weeks regardless of grass development.

Residual treatment effects following three harvest years were determined by cutting all plots when reed canarygrass was in early bloom. A uniform application of 25 pounds of nitrogen per acre was made on all plots in early spring.

The experimental design was a randomized complete block with three replications. All yield data, plant notes, and chemical data were taken 
from a basic plot of $6 \times 20$ feet. Adjacent plots treated in exactly the same manner as the basic plot were used for food reserve studies at Connecticut and Maryland. Dry matter yields were determined and botanical composition of the forage was estimated for all treatments at each location at each harvest. At each station, notes were taken throughout the study on vigor, stand density, and general appearance of the plants.

Chemical and biological analyses were made on selected treatments at some locations. In order to measure effect of previous treatments on the regrowth potential of reed canarygrass, six 3-inch plugs were taken from each plot immediately following a harvest and placed in a dark chamber at a temperature of $75^{\circ} \mathrm{F}$. The material was kept moist and was uniformly fertilized with nitrogen. Etiolated growth was then used as a measure of plant reserves or regrowth potential (54).

In vitro digestibility determinations of selected field samples from Connecticut and Maryland were made at West Virginia University according to the method described by Jung et al. (36). Chemical analyses for nitrogen-free extract (NFE), fiber, fat, and crude protein were made according to A.O.A.C. methods (6).
Carbohydrate analyses were made on reed canarygrass rhizomes collected at weekly intervals and dried at $158^{\circ} \mathrm{F}$. The tissue was ground to pass through a 40 -mesh screen. A $50 \mathrm{ml}$ aliquot of $.8 \mathrm{~N} \mathrm{HCl}$ was added to a $400 \mathrm{mg}$ sample of ground tissue and the sample was extracted for one hour at $212^{\circ} \mathrm{F}$. The samples were filtered following extraction and made up to a volume of $250 \mathrm{ml}$. A $5 \mathrm{ml}$ aliquot was tested for $r$ e d u cing power using the Shaffer-Somogyi method as described by Heinze and Murneek (31). The per cent glucose on a dry weight basis was calculated from the reducing power of the extracted solution.

Total fructose (free fructose, sucrose-fructose, fructosan-fructose) was determined by modifying the colorimetric techniques of Roe (50) and of McRary and Slattery (37). It was necessary to extract with $0.15 \mathrm{~N} \mathrm{HCl}$ instead of water and eliminate activated charcoal which interfered with the fructosan fraction.

Weather data were recorded near the plot sites at each station. Some of these data are presented in Appendix Tables $2 \mathrm{~A}$ and $2 \mathrm{~B}$ and general summaries are provided in Appendix Tables $2 \mathrm{C}, 2 \mathrm{D}$, and $2 \mathrm{E}$.

\section{EXPERIMENTAL RESULTS}

Dry Matter Production. Annual yields of dry matter (weed-free) produced by reed canarygrass during the three-year period 1960-62, ranged from 0.83 to 6.58 tons per acre at four northeastern states (Conn., N.Y., Pa., Md.). Many factors such as (a) plant density, (b) energy reserves, (c) soil fertility, (d) climate, (e) number of cuttings, (f) development of root system, (g) diseases and $(\mathrm{h})$ insects may influence the yields harvested from a grass stand. The re- sults reported herein were obtained from studies with reed canarygrass in which the effect or influence of certain (a-e) of these factors was examined when the grass was grown under specific management practices. The discussion and statistical analyses have been organized with regard to growing season since the development of the plants and the weather changed considerably from year to year.

\section{Yields Produced in the First Year After Seeding (1960)}

Yields of dry matter for the first cutting season (Table 2) were highest for New York (av. 5.02 tons per acre), intermediate for Connecticut (3.73) and Maryland (3.34), and lowest for Pennsylvania (3.00). This is surprising considering that precipitation during the growing season was less at New York than at other stations (Appendix Tables 2A, 2C). Higher total yields at New York, however, can largely be attributed to greater first harvest yields, whereas lower yields under Maryland or Pennsylvania conditions may be associated with the extent of plant development during establishment, soils, temperature during the growing season, or to lack of precipitation.

The number of harvests taken at the four 


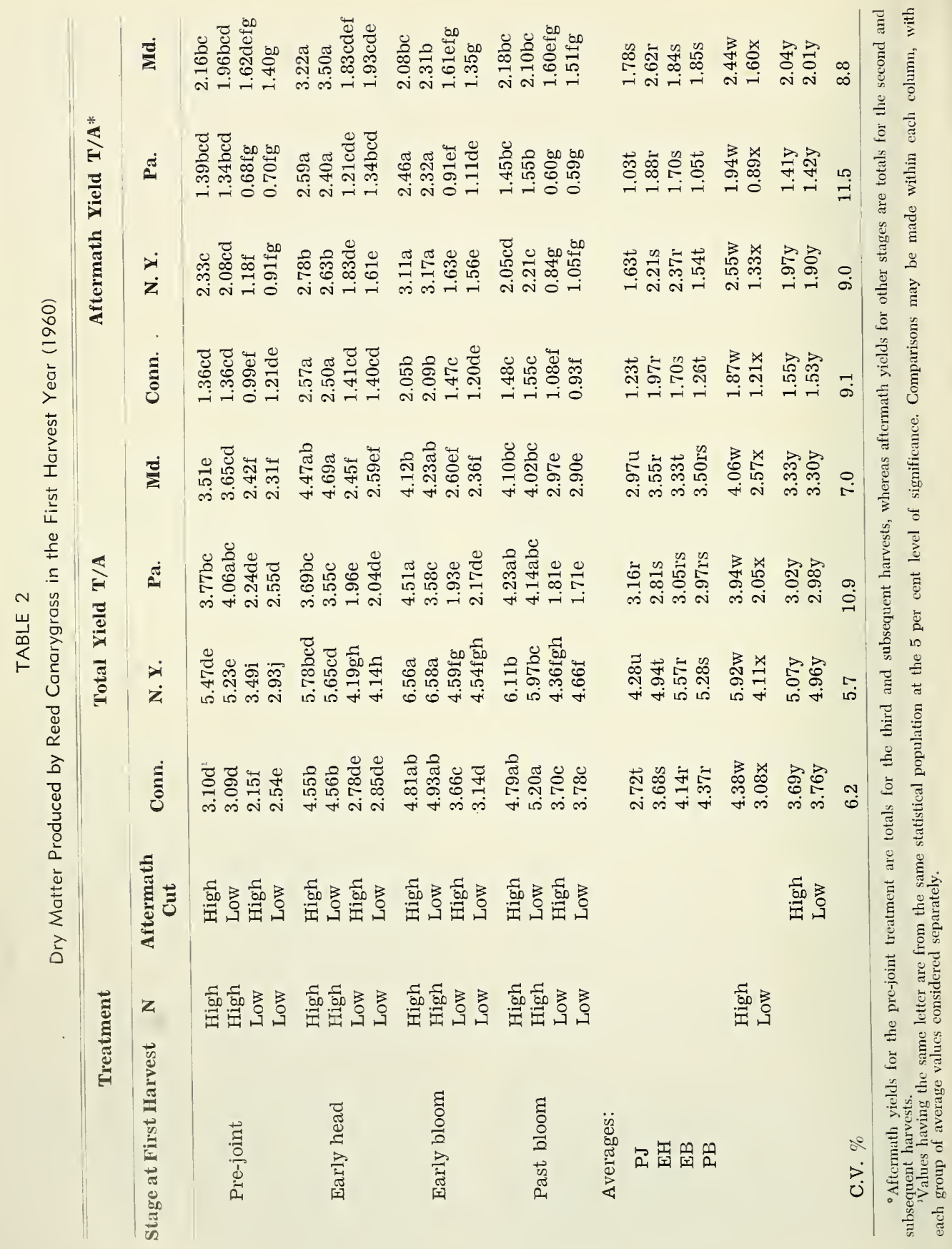


locations varied from 4 to 6 (Appendix Table 1). A larger number of harvests was obtained when the first harvest was taken at early rather than at late growth stages, except at Pennsylvania where four harvests were taken from all plots. At the other three locations, 5 or 6 cuttings were taken from plants harvested when the first growth was at the pre-joint stage. On the other hand, cutting the first growth at the past bloom stage permitted only 4 harvests.

Heading of reed canarygrass progressed northerly according to latitude within the region. At the early head stage of growth, there was a 13-day interval between the earliest and latest harvest dates. In contrast, blooming was observed at approximately the same time for all locations.

Analysis of variance (Appendix Table $3 \mathrm{~A}$ ) draws attention to the important effects of an additional 200 pounds of nitrogen per acre and of the time of first harvest. Where 300 pounds of nitrogen were applied, highest seasonal yields were obtained when the first cutting was removed at the early head stage for Maryland, the early bloom stage for New York and Pennsylvania, and the past bloom stage for Connecticut. Lodging at the past bloom stage reduced yields, particularly at New York. Where only 100 pounds of nitrogen were applied, highest seasonal yields were obtained when the first harvest was taken at the early head stage for Maryland and New York, and at the early bloom stage for Connecticut. Timing of the first harvest did not affect the total yield for the season in Pennsylvania, which may have been related to cutting all plots an equal number of times during the season. At both levels of nitrogen, total yields for the season were consistently low at all stations with the pre-joint cutting management.

The seasonal yield increases attributed to the additional 200 pounds of nitrogen were associated with stage of first harvest. They were greatest when the first harvest was taken at the early head stage of growth at Connecticut and Maryland, at the pre-joint or early bloom stage at New York, and at the past bloom stage at Pennsylvania. Yield increases were least when the first harvest was taken at the pre-joint stage of growth at Connecticut or Pennsylvania ans at the past bloom stage at Maryland or New York. These different responses may be attributed in part to a wide variation in seasonal yields for the four locations when reed canarygrass was first cut at the four different growth stages. Cutting later than the pre-joint stage increased dry matter yields in Connecticut from 1.45 to 1.90 tons per acre with the heavier rate of nitrogen and from .46 to 1.39 tons per acre with the lower rate of nitrogen, whereas only relatively small differences (i.e. about one third as much as those observed at Connecticut) were obtained at Pennsylvania by delaying the first harvest. Since all plots were cut according to the stage of growth attained by plants growing at the high rate of nitrogen, some of the difference in response at different locations can be attributed to the fact that plants growing at the low rate of nitrogen were not necessarily at the same stage of development.

Cutting the first aftermath at different heights did not appreciably influence total yield.

\section{Yields Produced in the Second Harvest Year (1961)}

More than five tons of reed canarygrass forage per acre were obtained with certain treatments at all locations except Maryland (Table 3 ). Precipitation for the region during the 1961 growing season (Appendix Table 2A) was quite similar to that received in 1960. However, precipitation was considerably higher at New York and lower at Connecticut in 1961 than in 1960. Part of the yield increase (Conn., Pa.) over the first harvest season was due to heavier applications of nitrogen fertilizer. In the previous year there were symptoms of nitrogen deficiency in some of the "high" nitrogen plots, so in 1961 there was an application of nitrogen after each harvest; and although the ratio of rates was left at $3: 1$, plots cut more often received more fertilizer (Appendix Table 1). The "high" nitrogen treatments received from 325 to 400 pounds of nitrogen per acre with an average of 353 pounds of nitrogen for all locations. The "low" nitrogen treatments received from 125 to 150 pounds of nitrogen with an average of 134 pounds applied for the four locations. Even though the "low" rates were increased, there was an average increase in yield of 64 per cent for the "high" rate at the four locations. The 


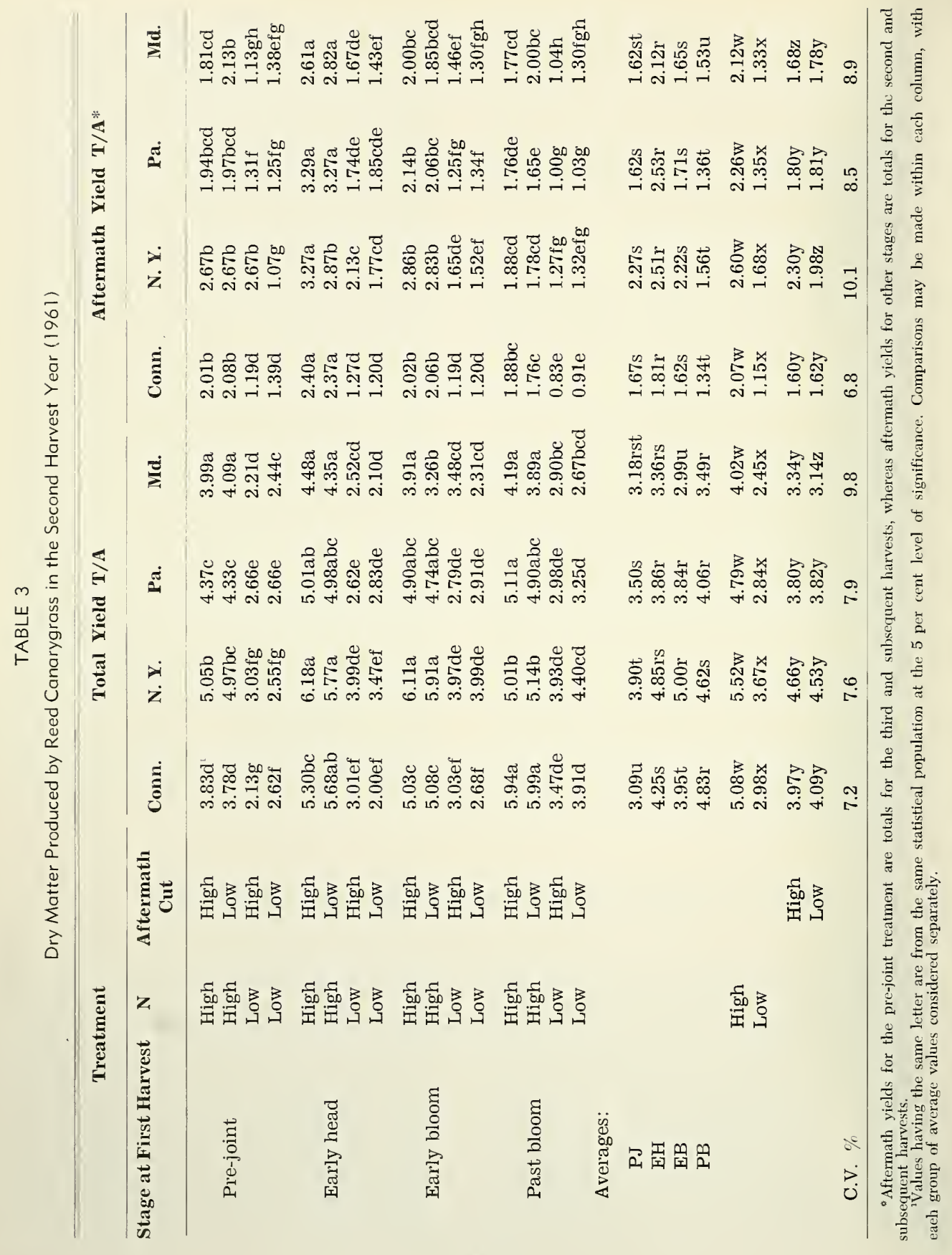


effect of abundant moisture and slightly higher levels of nitrogen are reflected most in the lowest yields recorded. All yields exceeded two tons of dry matter per acre. One more harvest was usually obtained if the first growth was taken at the pre-joint or early head stages rather than at the early or past bloom stages, except at Pennsylvania where 4 harvests were again taken from all treatments (Appendix Table 1).

Statistical analyses of total dry matter yields (Appendix Table 3B) show a trend similar to that observed the first year, i.e. effect of stage of growth when the first harvest was taken and nitrogen fertilization were statistically significant.

The influence of stage of growth at the first cutting on seasonal total yield was more consistent the second year than the first. At the high nitrogen levels, yields were highest when the first growth was harvested at the early head stage of growth. At the lower level of nitrogen, highest yields were harvested when the first cutting was taken at the past bloom stage of growth. Lodging might again explain the depression of yields when the grass was cut late and heavily fertilized. In the second year as in the first, the combination of the lower level of nitrogen and cutting the first growth at the prejoint stage was less productive than other treatments.

Additional nitrogen was most effective in raising yield when the first harvest was taken at the early head stage of growth. This was true at all locations, unlike the observations of 1960 . Additional nitrogen was least effective when the first harvest was taken at the pre-joint stage of growth at Connecticut and Pennsylvania, at early bloom at Maryland, and at the past bloom stage of growth at New York. Again, reed canarygrass responded most to the cutting managements imposed on the spring growth at Connecticut and least under Pennsylvania conditions with the response being three times greater in Connecticut than in Pennsylvania, just as it was the first year.

Cutting the first aftermath to different stubble heights significantly modified total yields only at Maryland during 1961. Higher yields were obtained when the aftermath was cut to a height of $3 \frac{1}{2}$ inches than when cut to a height of $1 \frac{1 / 2}{2}$ inches.

\section{Yields Produced in the Third Year (1962)}

The growth of reed canarygrass was limited by low soil moisture at all locations (Appendix Table 2A). Precipitation during the growing season was approximately 65 per cent of the amount received in 1961. Average yields for the third harvest year were reduced 34 per cent in Connecticut, 42 per cent in Maryland, 55 per cent in New York, and 60 per cent in Pennsylvania compared with respective yields produced in 1961 with more moisture (Table 4). Under New York conditions, gypsum blocks buried at depths of $4,8,12$, and 16 inches beneath the soil surface indicated that available soil moisture was never above 33 per cent from mid-June to mid-September. Drought reduced the number of cuttings taken from all plots except those cut first at the pre-joint growth stage (Appendix Table 1). Even so, yield reduction (average of all locations) was greatest (53 per cent) for the pre-joint defoliation treatment and least (42 per cent) when the first cutting was taken at the early bloom stage of growth. Yields were affected slightly less by drought where the higher level of nitrogen was used (46 compared with 51 per cent reduction).

Analyses of variance continued to provide evidence of important effects of nitrogen and time of first harvest on total yields (Appendix Table 3C). With the "high" nitrogen treatments, highest yields were obtained when the first growth was harvested at early bloom at Connecticut and New York and at the past bloom stage at Maryland and Pennsylvania. When the lower level of nitrogen fertilizer was applied, stage of growth at first cut did not affect yield except in New York, where harvest at early bloom was advantageous.

Extra nitrogen produced more response at Connecticut and Maryland than at New York and Pennsylvania. The greatest benefit was derived from the additional nitrogen by cutting the first growth at widely differing stages at different stations. Least successful use of the extra nitrogen was generally associated with the pre-joint harvest schedule.

No significant effects on yield were produced by varying the height of mowing the aftermath. 


\section{Aftermath Production in the First Year (1960)}

With little forage available in most permanent bluegrass pastures in the Northeast from late June until September, an important objective of this study was to determine the influence of nitrogen fertilization and cutting management on aftermath production.

Aftermath yields of dry matter at the four locations in 1960 varied from 0.59 tons per acre to 3.50 tons per acre (Table 2). Although there was more moisture available during the growing season at Connecticut than at other stations, yields were less at Connecticut than at New York or Maryland. Aftermath production for a particular location was usually tripled with optimum management. High yields of aftermath were associated with the heavier use of nitrogen and removing the spring growth at either the early head or early bloom stage of growth; low yields were usually associated with the lower rate of nitrogen fertilizer and harvesting the first crop at either the pre-joint or past bloom stage of growth. Response to additional nitrogen was greatest when the first harvest had been taken at either head emergence (Conn., Md.) or early bloom (N. Y., Pa.) and was smallest when the grass was cut first at the pre-joint stage of growth.

Varying the cutting height had, on the whole, little effect on regrowth. The effect of stubble height was measured principally in the third harvest and to a lesser extent in later cuttings.

\section{Aftermath Production in the Second Year (1961)}

A more uniform response to fertilizer and cutting treatments was observed in the aftermath at the four locations the second year
(Table 3) than the first year. The highest yields of aftermath were obtained with the high level of nitrogen, following cutting at the early head

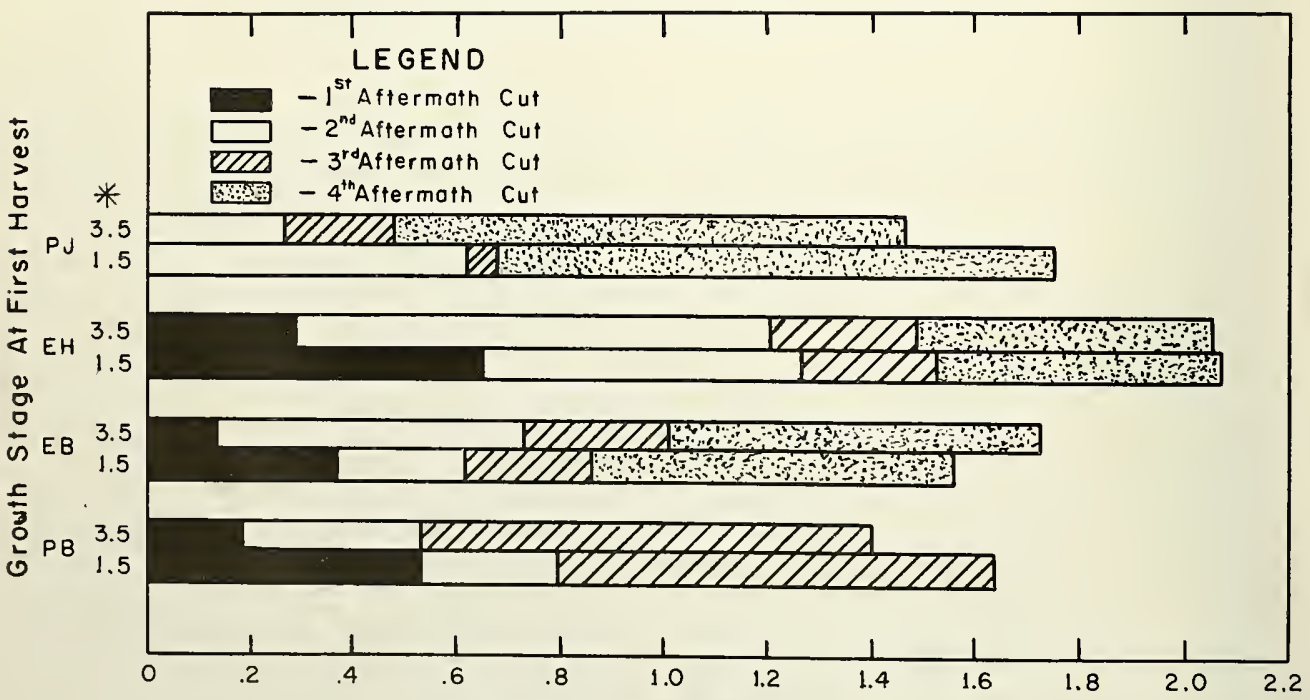

Tons Dry Matter Per Acre

Figure 1. Distribution of aftermath yields at Maryland in 1961. ( ${ }^{\circ}$ Differential cutting height-inches-was imposed on one aftermath crop.) 
stage of growth. With only one exception, the lowest aftermath yields followed the use of the lower level of nitrogen and harvesting at the past bloom growth stage.

Using more nitrogen fertilizer was most effective in increasing yields of aftermath when the first cut was made at the early head growth stage. At Maryland, aftermath production was influenced by time of first harvest and height of cutting the first aftermath, but only in conjunction with the higher rate of nitrogen. Stands cut first at pre-joint or past bloom produced more aftermath when cut low, whereas stands cut at other stages yielded as much or more when the aftermath was cut high (Figure 1). In the latter instances, yield reductions as- sociated with cutting the first aftermath high were compensated for in the next harvest. This was related to soil moisture which was more plentiful during growth of aftermath following cutting at early head or early bloom than following cutting at the other stages. In addition, tiller development may have been retarded by $\mathrm{higher}$ temperatures when the differential height of cut was imposed (July) on plants previously cut at pre-joint or at past bloom than when this was imposed (June) on plants previously cut at early-head or early-bloom (Appendix Tables 1, 2B). This serves to indicate the critical interactions between temperature, moisture, and stage of plant development as related to cutting management.

\section{Aftermath Production in the Third Year (1962)}

Under more adverse conditions in the third year, the aftermath production was again variable with regard to treatment effects (Table 4). Nevertheless, yields did not appear to be highly related to climatic conditions. Precipitation was similar at New York, Pennsylvania, and Maryland and bi-weekly air temperatures were similar at Connecticut: New York, and Pennsylvania (Appendix Tables 2A, 2B), yet the yields follow neither of these patterns.

Aftermath production was generally highest following cutting at the early bloom stage of growth with the higher level of nitrogen; but in three out of four locations, cutting at some other growth stage also resulted in high yields. In fact, cutting at each of the four growth stages resulted in high yields of aftermath at one or more locations. Low aftermath yields were associated with the same treatments as in the previ- ous seasons. At Pennsylvania, however, time of first harvest had no effect on yield with the lower level of nitrogen.

With limited moisture, yields associated with the most favorable treatments were 54 per cent lower the third harvest year than the second year, whereas a 65 per cent reduction was noted for the least favorable treatments. While aftermath yields were low, particularly in Pennsylvania, it should be noted that these yields were obtained during one of the most severe droughts ever recorded for the region.

Aftermath response to nitrogen depended on time of first harvest; and, in addition, the most beneficial time of first harvest varied with location. In Connecticut, leaving a higher stubble generally raised yields when the heavier rate of nitrogen was used, particularly after a first cut at the early head growth stage.

\section{Regrowth Potential}

Regrowth of reed canarygrass following harvest of the first crop was thought to be affected by the quantity of energy reserves contained in the stubble, rhizomes, and roots. Regrowth potential was evaluated at Connecticut and Maryland each year by measuring dry matter produced by sod plugs transferred from the plots to a dark room immediately following the first cutting at each of the four growth stages.
Etiolated growth was observed to depend upon treatment, location, season, and year. Large differences in etiolated growth following spring harvests were observed at Connecticut the first year, whereas few differences were noted under Maryland conditions (Table 5) where air temperatures were approximately 10 degrees higher than at Connecticut (Appendix Table 2B). Regrowth potential increased under Connecticut 


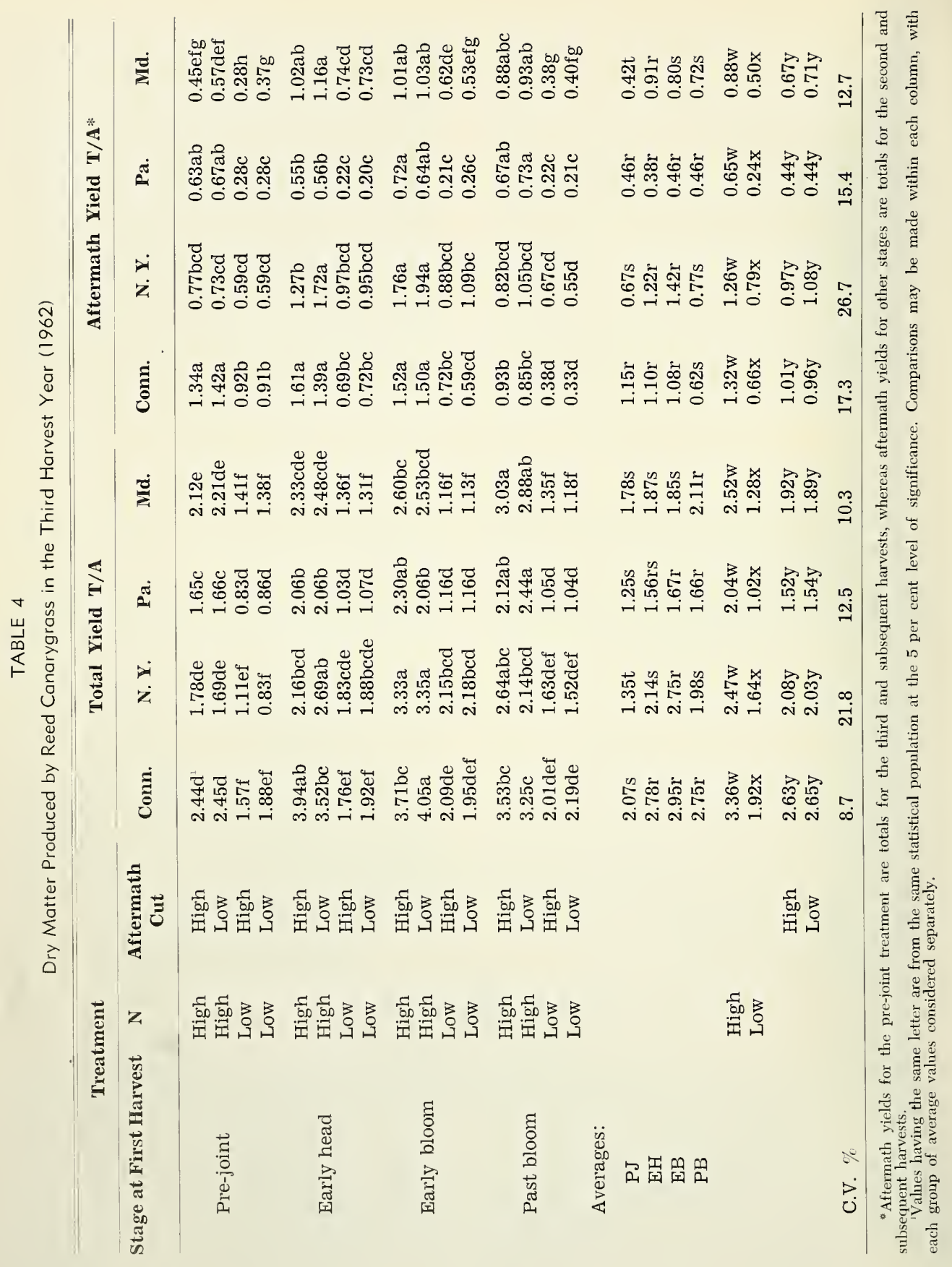


conditions as the time of first harvest was delayed. The effect of differential cutting height on regrowth potential was only of importance immediately following the harvest in which the treatment was imposed; regrowth potential was 33 per cent higher in plants with taller stubble.

Considerable attention was given to designing a uniform procedure for these evaluations, yet procedure still may account for some of the variation between locations because temperature and relative humidity were not controlled in the dark chambers. However, conditions were the same for all materials tested at a particular location in a given year.

Differences in growth and climate in the fall could have had a pronounced effect on energy reserves the following winter and spring: This concept is illustrated in Tables 5,6 , and 7 which show that the reserve status of plants varied for the fall of each year at each location.

Regrowth potential during the spring of the second year was generally greater than that ob-

TABLE 5

Etialated Growth of Reed Canarygrass in the First Harvest Year (1960)

\section{Dry Matter per Tiller (mg)}

Treatment

Stage at First Harvest N Aftermath Cut

Spring Harvest*

Differential

Height Harvest

Md.

Conn. Md.

\begin{tabular}{|c|c|c|c|c|c|c|c|}
\hline & High & High & $0.7 \mathrm{f}^{1}$ & $4.6 \mathrm{abc}$ & $2.5 \mathrm{~g}$ & $3.6 \mathrm{ab}$ & $6.7 \mathrm{a}$ \\
\hline \multirow[t]{4}{*}{ Pre-joint } & High & Low & $0.8 \mathrm{f}$ & $5.4 a b c$ & $3.1 \mathrm{~g}$ & $3.7 \mathrm{ab}$ & $6.7 \mathrm{a}$ \\
\hline & Low & High & $1.8 \mathrm{f}$ & $6.0 \mathrm{a}$ & $3.1 \mathrm{~g}$ & $2.0 \mathrm{~b}$ & $3.3 \mathrm{f}$ \\
\hline & Low & Low & $1.3 \mathrm{f}$ & $5.6 a b$ & $3.2 \mathrm{~g}$ & $2.3 \mathrm{~b}$ & $4.2 \mathrm{def}$ \\
\hline & High & High & $2.4 \mathrm{ef}$ & $3.9 \mathrm{c}$ & $3.9 \mathrm{fg}$ & $3.4 \mathrm{a}$ & $5.1 \mathrm{~cd}$ \\
\hline \multirow{4}{*}{ Early head } & High & Low & $4.6 \mathrm{de}$ & $4.2 \mathrm{bc}$ & $4.5 \mathrm{fg}$ & $3.0 \mathrm{a}$ & $5.2 \mathrm{bcd}$ \\
\hline & Low & High & $5.9 \mathrm{~d}$ & $4.4 \mathrm{bc}$ & $4.8 \mathrm{efg}$ & $2.0 \mathrm{~b}$ & $3.2 \mathrm{f}$ \\
\hline & Low & Low & $6.0 \mathrm{~d}$ & $4.6 a b c$ & $3.7 \mathrm{~g}$ & $2.0 \mathrm{~b}$ & $3.8 \mathrm{ef}$ \\
\hline & High & High & $9.3 c$ & $5.1 \mathrm{abc}$ & $8.0 \mathrm{~cd}$ & $2.2 \mathrm{~b}$ & $5.7 \mathrm{abc}$ \\
\hline \multirow[t]{4}{*}{ Early bloom } & High & Low & $8.5 c$ & $5.2 \mathrm{abc}$ & $7.2 \mathrm{de}$ & $2.4 \mathrm{~b}$ & $5.8 \mathrm{abc}$ \\
\hline & Low & High & $11.2 \mathrm{~b}$ & $4.8 \mathrm{abc}$ & $10.0 \mathrm{bc}$ & $2.5 b$ & $4.8 \mathrm{cde}$ \\
\hline & Low & Low & $10.9 b c$ & $5.1 \mathrm{abc}$ & $6.3 \mathrm{def}$ & $1.9 \mathrm{~b}$ & $4.2 \mathrm{def}$ \\
\hline & High & High & $15.2 \mathrm{a}$ & $4.7 \mathrm{abc}$ & $10.6 \mathrm{ab}$ & $3.2 \mathrm{ab}$ & $6.3 \mathrm{ab}$ \\
\hline \multirow[t]{3}{*}{ Past bloom } & High & Low & $13.1 \mathrm{ab}$ & $5.2 \mathrm{abc}$ & $7.2 \mathrm{de}$ & $3.5 \mathrm{ab}$ & $6.8 \mathrm{a}$ \\
\hline & Low & High & $10.7 b c$ & $4.3 \mathrm{bc}$ & $12.7 \mathrm{a}$ & $5.2 \mathrm{a}$ & $4.2 \mathrm{def}$ \\
\hline & Low & Low & $13.8 \mathrm{a}$ & $4.2 b c$ & $7.2 \mathrm{de}$ & $5.1 \mathrm{a}$ & $3.4 \mathrm{f}$ \\
\hline \multicolumn{8}{|l|}{ Averages: } \\
\hline $\mathrm{PJ}$ & & & $1.2 \mathrm{u}$ & $5.4 \mathrm{r}^{\circ}$ & $3.0 \mathrm{t}$ & $2.9 \mathrm{~s}$ & $5.2 \mathrm{r}$ \\
\hline $\mathrm{EH}$ & & & $4.7 \mathrm{t}$ & $4.3 \mathrm{~s}$ & $4.2 \mathrm{~s}$ & $2.6 \mathrm{~s}$ & $4.3 \mathrm{~s}$ \\
\hline EB & & & $10.0 \mathrm{~s}$ & $5.0 \mathrm{rs}$ & $7.9 \mathrm{r}$ & $2.2 \mathrm{~s}$ & $5.1 \mathrm{r}$ \\
\hline \multirow[t]{5}{*}{ PB } & & & $13.2 \mathrm{r}$ & $4.6 \mathrm{~s}$ & $8.6 r$ & $4.2 \mathrm{r}$ & $5.2 \mathrm{r}$ \\
\hline & High & & $6.8 \mathrm{w}$ & $4.8 w$ & $6.3 \mathrm{w}$ & $3.1 \mathrm{w}$ & $6.0 \mathrm{w}$ \\
\hline & Low & & $7.7 \mathrm{w}$ & $4.9 w$ & $6.3 \mathrm{w}$ & $2.9 \mathrm{w}$ & $3.9 \mathrm{x}$ \\
\hline & & High & $7.2 \mathrm{y}$ & $4.7 \mathrm{y}$ & $7.2 \mathrm{y}$ & $3.0 \mathrm{y}$ & $4.9 y$ \\
\hline & & Low & $7.4 \mathrm{y}$ & $4.9 \mathrm{y}$ & $5.4 \mathrm{z}$ & $3.0 \mathrm{y}$ & $5.0 \mathrm{y}$ \\
\hline$\%$ & & & & 15.3 & 20.1 & & 11.5 \\
\hline
\end{tabular}

* On these sampling dates the plants had not been subjected to the differential height of cut.

${ }^{2}$ Values having the same letter are from the same statistical population at the 5 per cent level of significance. Comparisons may be made within each column, with each group of average values considered separately. 
tained the first year, particularly so following cutting at early stages of growth (Tables 5, 6). Etiolated growth was greater at Maryland than at Connecticut in spring and the reverse was true in the fall. In addition, response to the treatments was not uniform in spring or fall. In fact, harvesting at different stages of growth resulted in dissimilar effects on regrowth potential at the two locations. As was the case in the first harvest year, regrowth potential immediately following the harvest at differential heights was one-third greater for plants with the taller stubble. But at other times during the season, the effect of cutting at differential heights was negligible.

On the other hand, regrowth potential following cutting at the pre-joint growth stage was greater than regrowth potential following cutting at later growth stages at both locations the third year (Table 7). Drought and high temperatures during the last two weeks of May (Appendix Tables 2A, 2B, 2E) were probably re-

TABLE 6

Etiolated Growth of Reed Canarygrass in the Second Harvest Year (1961)

Dry Matter per Tiller (mg)

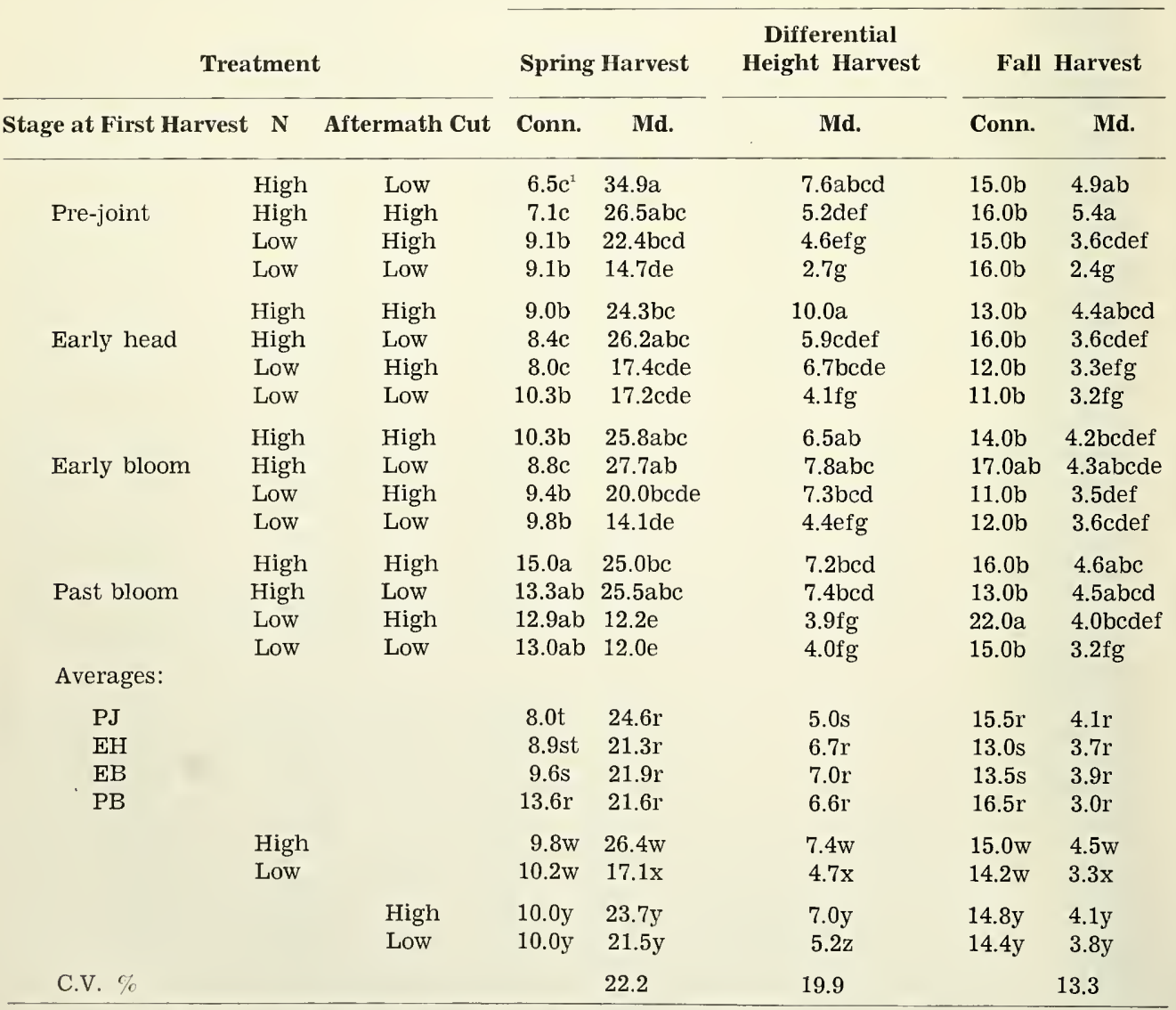

${ }^{1}$ Values having the same letter are from the same statistical population at the 5 per cent level of significance. Comparisons may be made within cach column, with each group of average values considered separately. 
sponsible for a reduction in regrowth potential following a harvest at the later growth stages.

The New York experiment included an extra set of plots that were harvested each spring at the mid-joint stage. Thus, they were cut between the pre-joint and early head treatments. This treatment was intended to tax the reserves of the plants rather severely by cutting off the stems as they began to elongate. It was assumed that cutting the stems and leaves after a brief period of photosynthesis would deplete the reserves more than earlier or later first crop har- vesting. This concept appeared to be corrtet the first year. Plants harvested at the mid-joint stage yielded less than plants harvested at any other growth stage. But this treatment was not as severe in the remaining harvest years. At the conclusion of the New York experiment in 1963, plugs were taken from all plots. Three successive weekly harvests of etiolated top growth indicated no effect of previous management; and therefore, it may be concluded that mobilizable reserves of all samples were comparable.

TABLE 7

Etiolated Growth of Reed Canarygrass in the Third Harvest Year (1962)

Dry Matter per Tiller (mg)

Treatment

Stage at First Harvest N Aftermath Cut
Spring Harvest

Conn. Md.

14.7ab

$18.2 \mathrm{a}$

$11.8 \mathrm{bcd}$

$13.9 \mathrm{bc}$

$11.0 \mathrm{~b}$

High

Low

High

Early head

High

High

Low High

Low

Low

High High

Early bloom

High

Low

Low

Low

High

Low

High High

Past bloom

High

Low

Low

Averages:

$\begin{array}{ll}\text { PJ } & \\ \text { EH } & \\ \text { EB } & \\ \text { PB } & \text { High } \\ & \text { Low }\end{array}$

\section{$4.4 \mathrm{~d}$}

$4.3 \mathrm{~d}$

$4.6 \mathrm{~d}$

$4.2 \mathrm{~d}$

$4.6 \mathrm{~d}$

$4.2 \mathrm{~d}$

$4.2 \mathrm{~d}$

$4.2 \mathrm{~d}$

$6.2 \mathrm{~cd}$

$5.4 \mathrm{~cd}$

$5.5 \mathrm{~cd}$

$5.2 \mathrm{~cd}$

\section{9 def}

$7.0 \mathrm{ef}$

$7.2 \mathrm{ef}$

7.1 ef

$6.8 \mathrm{ef}$

$10.6 \mathrm{cde}$

7.5ef

8.9def

8.7def

$7.4 \mathrm{ef}$

$5.9 \mathrm{f}$

$5.6 \mathrm{f}$

\section{Low}

High

Low

\begin{tabular}{lrrr} 
& $10.9 \mathrm{r}$ & $14.6 \mathrm{r}$ & $9.3 \mathrm{r}$ \\
& $4.4 \mathrm{~s}$ & $7.5 \mathrm{~s}$ & $8.2 \mathrm{r}$ \\
& $4.5 \mathrm{~s}$ & $8.4 \mathrm{~s}$ & $9.0 \mathrm{r}$ \\
& $5.6 \mathrm{~s}$ & $8.0 \mathrm{~s}$ & $9.4 \mathrm{r}$ \\
& $5.8 \mathrm{w}$ & $10.3 \mathrm{w}$ & $10.6 \mathrm{w}$ \\
High & $6.8 \mathrm{w}$ & $8.5 \mathrm{x}$ & $7.3 \mathrm{w}$ \\
Low & $6.3 \mathrm{y}$ & $8.9 \mathrm{y}$ & $8.8 \mathrm{y}$ \\
& $6.3 \mathrm{y}$ & $10.8 \mathrm{y}$ & $9.1 \mathrm{y}$ \\
\hline
\end{tabular}

C.V. \%

Fall Harvest

Conn.

$9.4 \mathrm{bcd}$

$12.9 \mathrm{a}$

$6.5 \mathrm{~d}$

$8.3 \mathrm{bcd}$

$10.0 \mathrm{abc}$

$9.3 \mathrm{~b}$

$6.8 \mathrm{~d}$

$6.8 \mathrm{~d}$

$10.7 \mathrm{ab}$

$11.0 \mathrm{ab}$

$6.4 \mathrm{~d}$

$7.8 \mathrm{~cd}$

$11.6 \mathrm{a}$

$10.2 \mathrm{abc}$

$8.6 \mathrm{bcd}$

$7.1 d$

'Values having the same letter are from the same statistical population at the 5 per cent level of significance. Comparisons may be made within each column, with each group of average values considered separately. 


\section{Carbohydrate Reserves}

The content of available carbohydrates in the rhizomes of reed canarygrass harvested at the pre-joint (Figure 2) and early bloom (Figure 3) growth stages was determined periodically during the third harvest season at Connecticut. The available carbohydrate content decreased during the early spring growth period and then accumulated slightly just prior to the elongation of the stem. Depletion occurred again as the growing point was elevated (late May) and the seed head developed (early June). The depletion of available carbohydrates was more rapid and occurred at an earlier date when the higher level of nitrogen was applied, but the differences associated with nitrogen were small or of short duration. The available carbohydrate content usually decreased following the initiation of growth after a harvest. Cutting at the two growth stages did not, however, markedly affect the seasonal trends or the carbohydrate content. Regardless of the treatments imposed, the plants accumulated higher concentrations of available carbohydrates during the fall than at any time during the growing season. At the higher rate of nitrogen, rhizomes were heavier, but their carbohydrate concentrations were not affected.

Studies at Maryland indicated that a depletion of fructose content in the stubble, roots, and crowns occurred following a harvest at the past bloom stage (Figure 4). As at Connecticut, the sugar levels remained low until fall. The content of fructose was generally higher in the crown than in roots and least in the stubble. The increase in fructose content during the fall was much less in the stubble than in the other tissues.

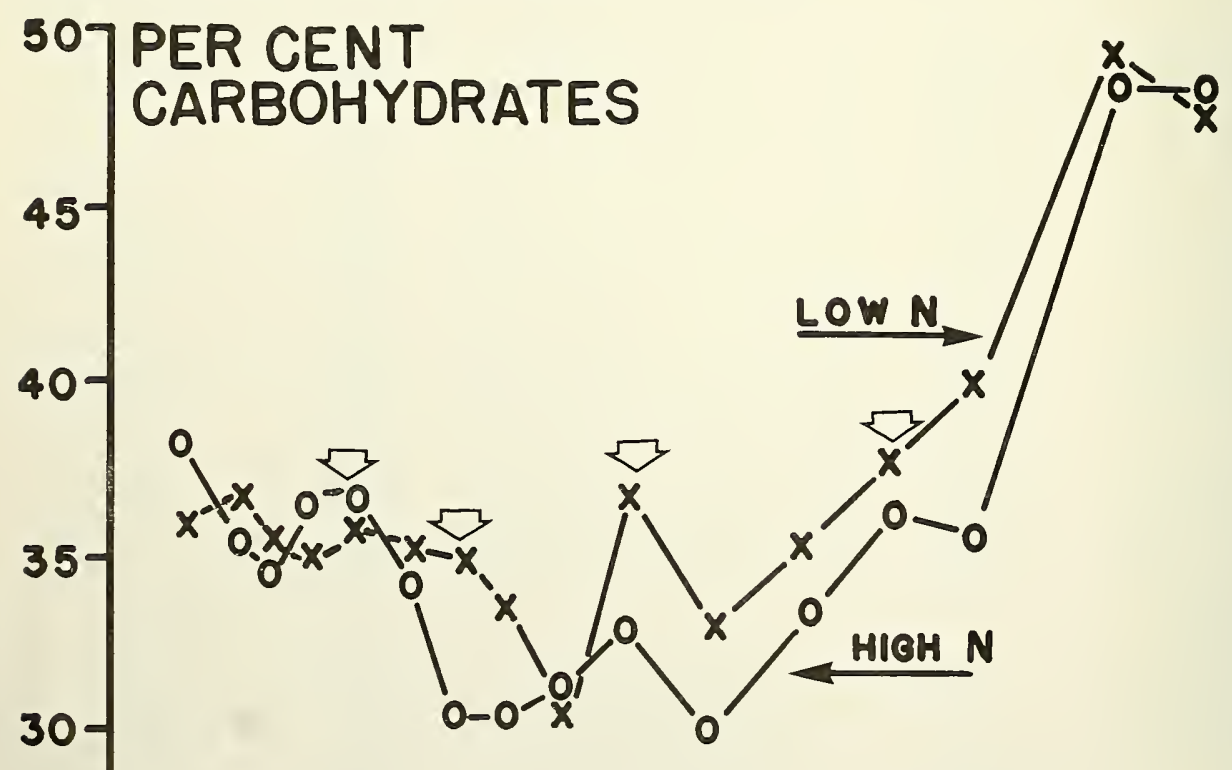

25

\section{APRIL MAY JUNE JULY AUG. SEPT. OCT.}

Figure 2. Influence of nitrogen fertilizer on the per cent of available carbohydrates in reed canarygrass rhizomes during the third havest season (1962) at Connecticut. First cutting was taken when plants were in the me-joint grouth stage. Arrows indicate cutting dates. 


\section{${ }^{50}$ PER CENT CARBOHYDRATES}

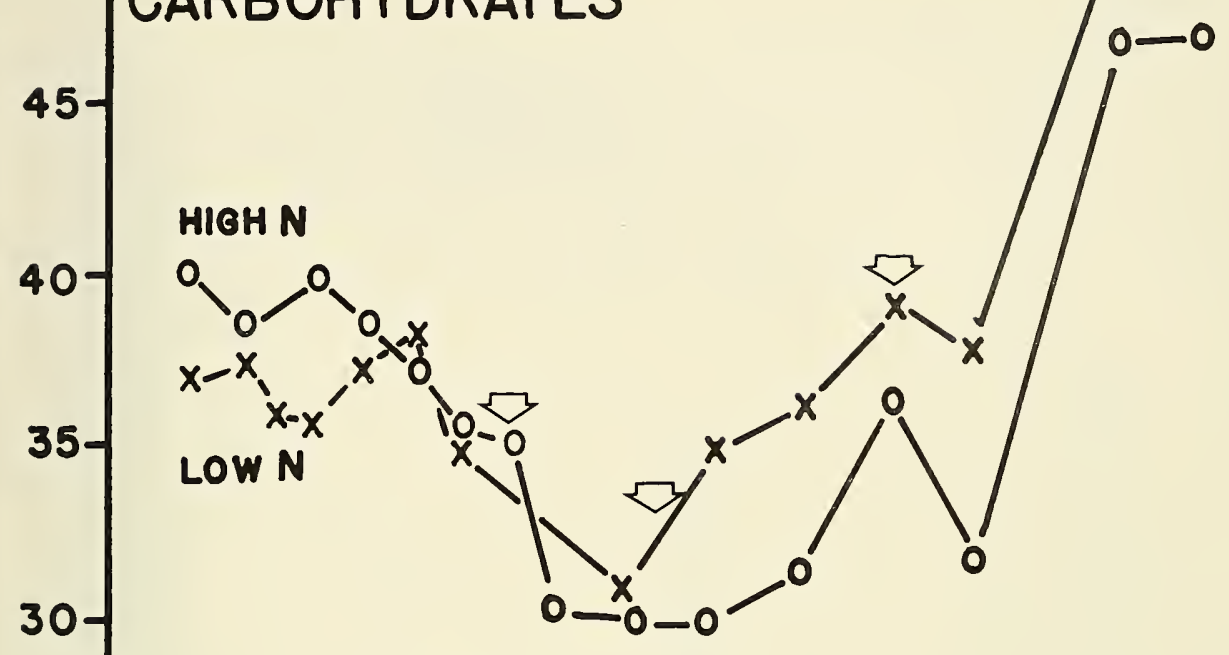

25

\section{APRIL MAY JUNE JULY AUG, TSEPT.}

Figure 3. Influence of nitrogen fertilizer on the per cent of available carbohydrates in reed canarygrass rhizomes during the third harvest season (1962) at Connecticut. First cutting was taken when the plants were in early bloom. Arrows indicate cutting dates.

Another study at Maryland was designed to determine the relationship between growth potential and fructose content of the stubble, roots, and crowns. There was almost complete exhaustion of fructose in all three tissues fol- lowing 40 days growth in the dark (Figure 5). A highly significant correlation of .748 was obtained for total fructose content and tiller growth in the dark.

\section{Persistence}

Stand ratings for ground cover were made in early spring each year. Data for the spring of the first harvest year are not presented because excellent, uniform stands were obtained. After one harvest year, very little effect of the management treatments could be detected (Table 8), although at Maryland a combination of the higher rate of nitrogen and the lower cutting height did thin stands significantly. Stands were good at the lower rate of nitrogen regardless of cutting management.

The vigor and persistence of reed canarygrass is demonstrated by the fact that even after two harvest years, the stands were not greatly altered by the 16 treatments except at New York (Table 9). Stands were drastically reduced at New York, and this was particularly so with harvesting either at the pre-joint or past bloom 


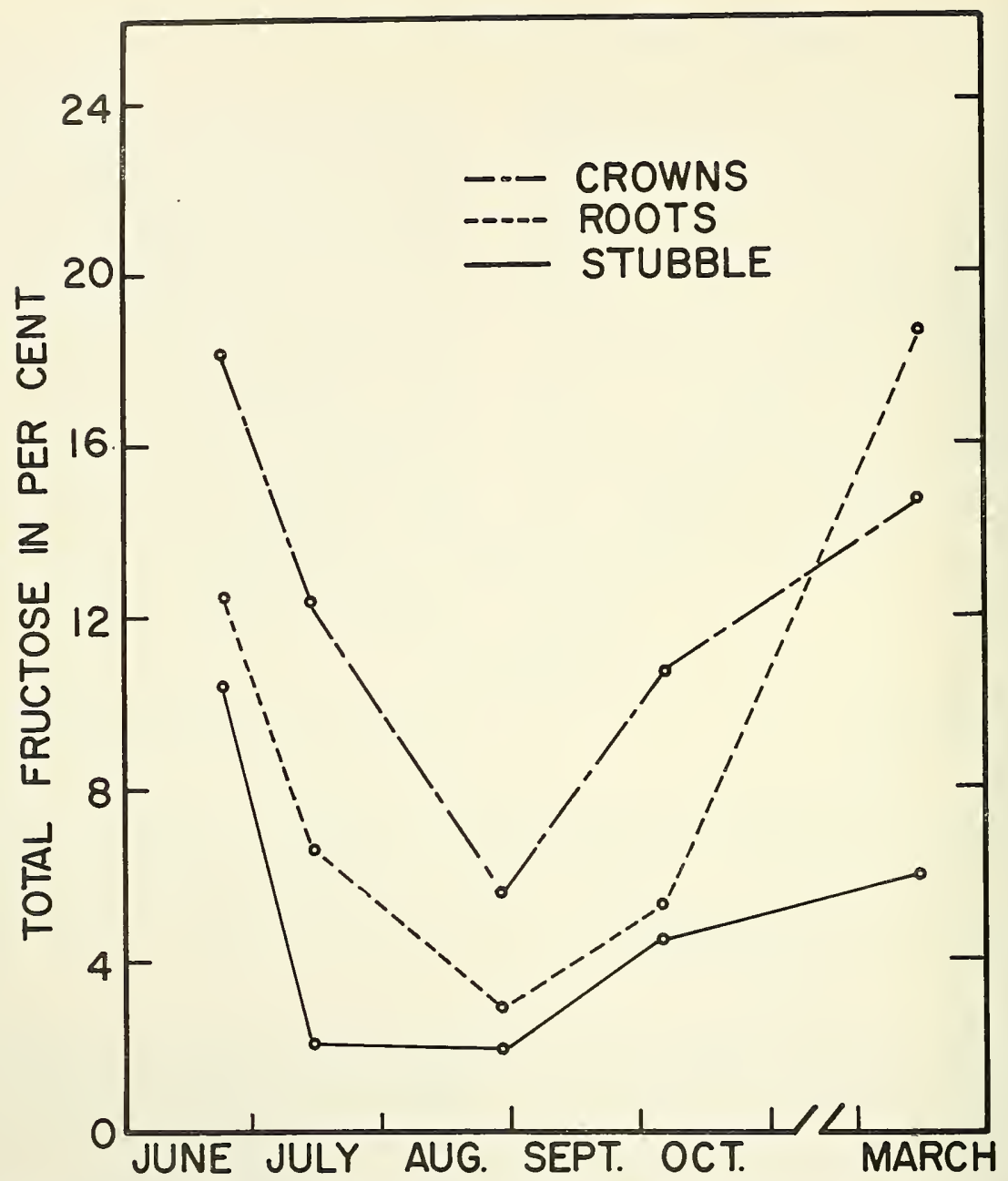

Figure 4. Seasonal distribution of total fructose (dry weight basis) for the stubble, roots, and crowns of reed canarygrass harvested at past bloom in 1961.

stages and when the high rate of nitrogen was applied. Quackgrass invaded the plots at New York, complicating stand ratings.

Following three years of harvesting with the specified management treatments, good ground cover was again noted at three of the locations (Table 10). Stands at New York were still considerably thinner than at the other locations. Ground cover at New York was best where plants were cut at early bloom; but in contrast to the previous year, rate of nitrogen fertilization had little effect. The trend at Maryland was similar; delaying harvest of the first crop usually resulted in better stands. A combination of the lower rate of nitrogen and a low cutting height at Maryland resulted in less ground cover, especially when the first harvest was delayed. 


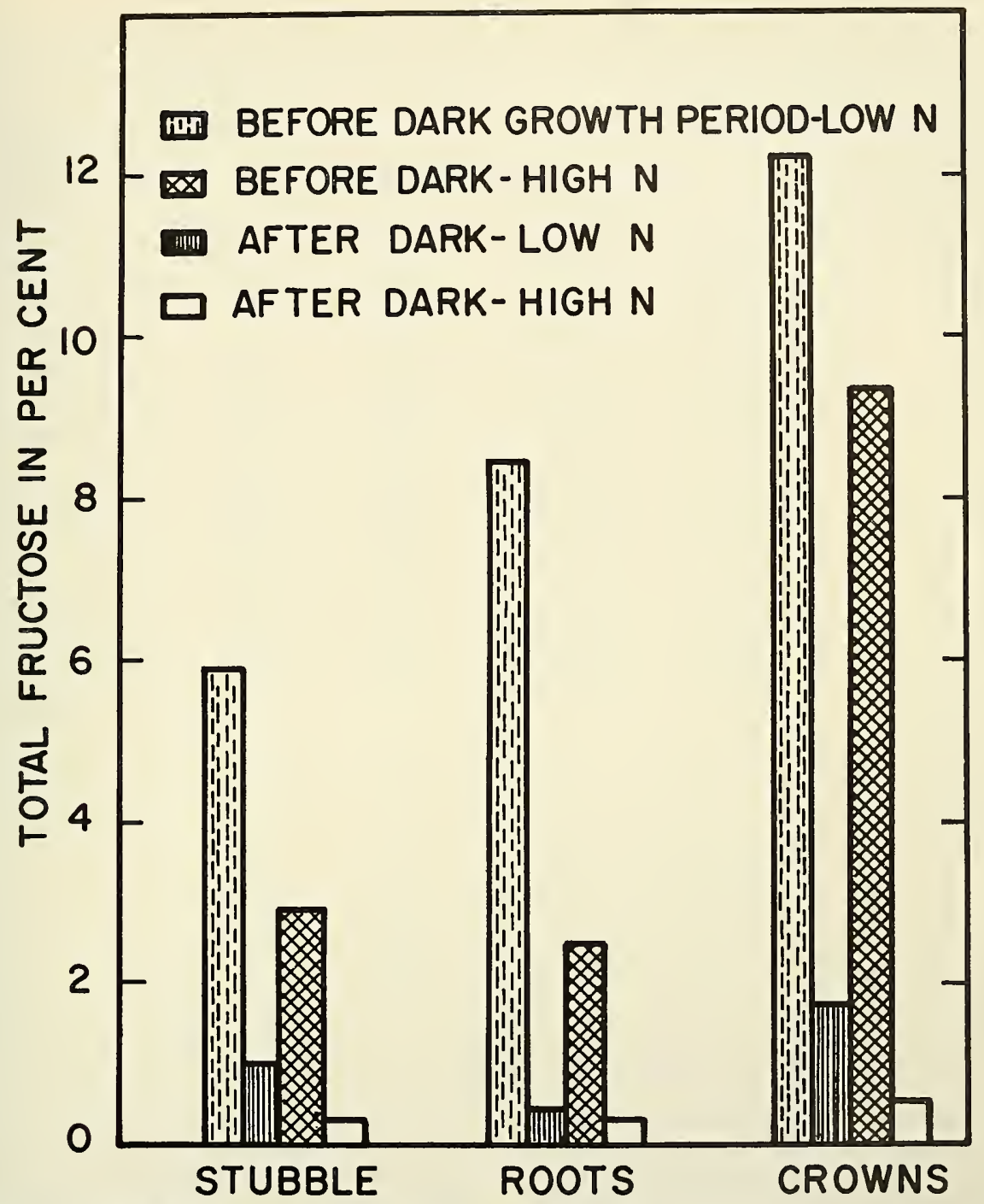

Figure 5. Utilization of fructose reserves by reed canarygrass tillers grown in the dark for 40 days. Plants were removed from the field October 1961 at College Park, Maryland.

\section{Residual Treatment Effects}

The accumulative effects of imposing cutting and fertilization treatments on reed canarygrass stands for three years were determined in the spring of 1963. A uniform rate of nitrogen was applied to all plots, and they were harvested at early bloom. Only a few effects could be attributed to previous cutting management (Table 11). Cutting the first crop at different stages of 
TABLE 8

Stand Ratings of Reed Canarygrass in the Spring of the Second Harvest Year (1961)

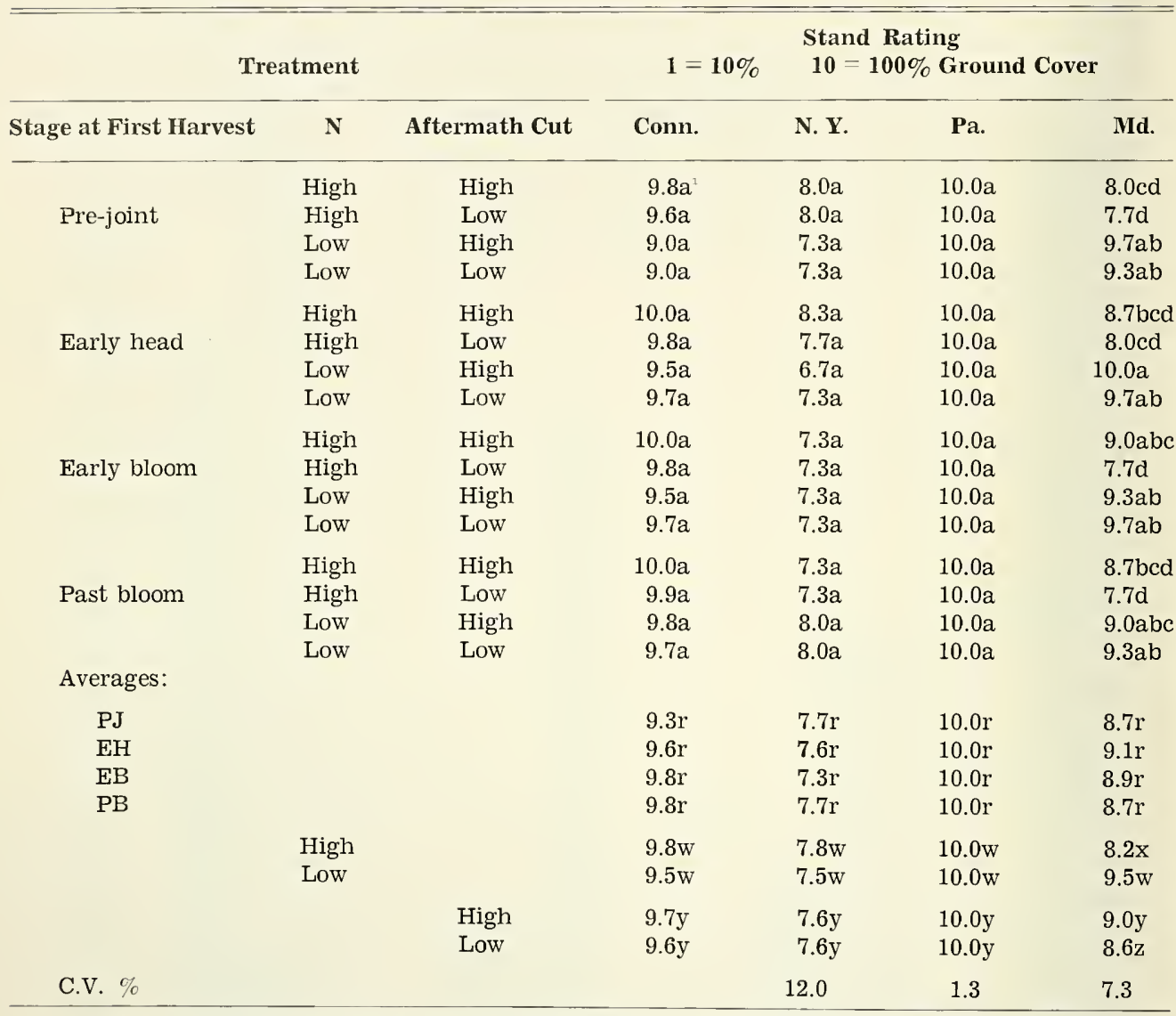

Values having the same letter are from the same statistical population at the 5 per cent level of significance. Comparisons may be made within each column, with each group of average values considered separately.

growth affected residual yields only at Pennsylvania, whereas cutting the first aftermath at different heights modified residual yields only at Maryland. Grass previously fertilized with the higher rate of nitrogen, produced higher residual yields at three locations, but in most in- stances this appeared to be a result of fertilizer carryover from the previous season. The high yields of dry matter which were harvested at New York indicate that the low stand ratings for this station were no indication of yield potential.

\section{Nutritive Value}

It was imperative for two reasons that the nutritive value of reed canarygrass forage be estimated. Knowledge of the effect of stage of maturity on the nutritive value of other forages suggests that the treatments imposed in this study could greatly alter the nutritive value of 
TABLE 9

Stand Ratings of Reed Canarygrass in the Spring of the Third Harvest Year (1962)

\begin{tabular}{|c|c|c|c|c|c|c|}
\hline \multicolumn{3}{|c|}{ Treatment } & \multicolumn{4}{|c|}{$\begin{array}{l}\text { Stand Rating } \\
10=100 \% \text { Ground Cover }\end{array}$} \\
\hline Stage at First Harvest & $\mathbf{N}$ & Aftermath Cut & Conn. & N. $\mathbf{Y}$. & Pa. & Md. \\
\hline \multirow{4}{*}{ Pre-joint } & High & High & $9.1 \mathrm{a}^{1}$ & $3.3 \mathrm{~cd}$ & $10.0 \mathrm{a}$ & $9.0 \mathrm{~d}$ \\
\hline & High & Low & $8.6 \mathrm{a}$ & $3.3 \mathrm{~cd}$ & $10.0 \mathrm{a}$ & $9.0 \mathrm{~d}$ \\
\hline & Low & High & $9.0 \mathrm{a}$ & $5.0 \mathrm{abc}$ & $10.0 \mathrm{a}$ & $10.0 \mathrm{a}$ \\
\hline & Low & Low & $9.3 \mathrm{a}$ & $3.0 \mathrm{~d}$ & $10.0 \mathrm{a}$ & $9.8 \mathrm{ab}$ \\
\hline \multirow{4}{*}{ Early head } & High & High & $9.2 \mathrm{a}$ & $3.7 \mathrm{bcd}$ & $10.0 \mathrm{a}$ & $9.7 \mathrm{ab}$ \\
\hline & High & Low & $9.5 \mathrm{a}$ & $3.7 \mathrm{bcd}$ & $10.0 \mathrm{a}$ & $9.3 \mathrm{~cd}$ \\
\hline & Low & High & $9.5 \mathrm{a}$ & $5.3 \mathrm{ab}$ & $10.0 \mathrm{a}$ & $10.0 \mathrm{a}$ \\
\hline & Low & Low & $9.5 \mathrm{a}$ & $5.7 \mathrm{a}$ & $10.0 \mathrm{a}$ & $10.0 \mathrm{a}$ \\
\hline \multirow{4}{*}{ Early bloom } & High & High & $9.2 \mathrm{a}$ & $4.0 \mathrm{abcd}$ & $10.0 \mathrm{a}$ & $9.5 \mathrm{bc}$ \\
\hline & High & Low & $9.5 \mathrm{a}$ & 4.0abcd & $10.0 \mathrm{a}$ & $9.2 \mathrm{~cd}$ \\
\hline & Low & High & $9.5 a$ & $5.3 a b$ & $10.0 \mathrm{a}$ & $9.8 \mathrm{ab}$ \\
\hline & Low & Low & $9.5 \mathrm{a}$ & $5.0 \mathrm{abc}$ & $10.0 \mathrm{a}$ & $10.0 \mathrm{a}$ \\
\hline \multirow{4}{*}{ Past bloom } & High & High & $9.5 \mathrm{a}$ & $3.0 \mathrm{~d}$ & $10.0 \mathrm{a}$ & $9.7 \mathrm{ab}$ \\
\hline & High & Low & $9.2 \mathrm{a}$ & $3.7 \mathrm{bcd}$ & $10.0 \mathrm{a}$ & $9.5 b c$ \\
\hline & Low & High & $9.8 \mathrm{a}$ & 4.3abcd & $10.0 \mathrm{a}$ & $10.0 \mathrm{a}$ \\
\hline & Low & Low & $9.9 \mathrm{a}$ & $2.7 \mathrm{~d}$ & $10.0 \mathrm{a}$ & $9.9 \mathrm{ab}$ \\
\hline \multicolumn{7}{|l|}{ Averages: } \\
\hline PJ & & & $9.0 \mathrm{r}^{\circ}$ & $3.7 \mathrm{~s}$ & $10.0 \mathrm{r}$ & $9.5 \mathrm{~s}$ \\
\hline $\mathrm{EH}$ & & & $9.6 \mathrm{r}$ & $4.6 \mathrm{r}$ & $10.0 \mathrm{r}$ & $9.8 \mathrm{r}$ \\
\hline $\mathrm{EB}$ & & & $9.4 \mathrm{r}$ & $4.6 \mathrm{r}$ & $10.0 \mathrm{r}$ & $9.6 \mathrm{~s}$ \\
\hline \multirow[t]{5}{*}{$\mathrm{PB}$} & & & $9.6 \mathrm{r}$ & $3.4 \mathrm{~s}$ & $10.0 \mathrm{r}$ & $9.8 \mathrm{r}$ \\
\hline & High & & $9.3 \mathrm{w}$ & $3.8 \mathrm{x}$ & $10.0 \mathrm{w}$ & $9.4 \mathrm{x}$ \\
\hline & Low & & $9.5 \mathrm{w}$ & $4.6 \mathrm{w}$ & $10.0 \mathrm{w}$ & $9.9 \mathrm{w}$ \\
\hline & & High & $9.4 \mathrm{y}$ & $4.4 y$ & $10.0 \mathrm{y}$ & $9.7 y$ \\
\hline & & Low & $9.4 \mathrm{y}$ & $4.0 \mathrm{y}$ & $10.0 \mathrm{y}$ & $9.6 \mathrm{z}$ \\
\hline C.V. $\%$ & & & & 4.0 & & 4.5 \\
\hline
\end{tabular}

${ }^{1}$ Values having the same letter are from the same statistical population at the 5 per cent level of significance. Comparisons may be made within each column, with each group of average values considered separately.

reed canarygrass. Secondly, previous investigations with reed canarygrass indicate that the major factor limiting the utilization of this species by farmers is its low feed value.

Chemical analyses for the first crop produced in the first and third harvest years are presented in Table 12. In general, nitrogen-free extract (NFE) and fiber content increased with each advance in plant maturity, whereas the fat and crude protein content decreased. Increasing the rate of nitrogen fertilization lowered the content of nitrogen-free extract and raised the content of crude protein. No consistent effect of nitrogen fertilization on content of fiber or fat was observed. The importance of these chemical analyses to development of a management system is illustrated by the observation that plots cut at the heading stage produced over the year approximately 400 pounds more crude protein per acre with the high rate of nitrogen than with the low rate.

The digestibility of certain forage samples collected in the third harvest year was determined with an artificial rumen te $\mathrm{chnique}$ (Table 13). Drastic reductions of the digestibility of protein and dry matter were observed 
TABLE 10

Stand Ratings of Reed Canarygrass in the Spring of the Residual Harvest Year (1963)

\begin{tabular}{|c|c|c|c|c|c|c|}
\hline \multicolumn{3}{|c|}{ Treatment } & \multicolumn{4}{|c|}{$\begin{array}{l}\text { Stand Rating } \\
10=100 \% \text { Ground Cover }\end{array}$} \\
\hline Stage at First Harvest & $\mathbf{N}$ & Aftermath Cut & Conn. & N. Y. & Pa. & Md. \\
\hline Pre-joint & $\begin{array}{l}\text { High } \\
\text { High } \\
\text { Low } \\
\text { Low }\end{array}$ & $\begin{array}{l}\text { High } \\
\text { Low } \\
\text { High } \\
\text { Low }\end{array}$ & $\begin{array}{l}10.0 \mathrm{a}^{1} \\
10.0 \mathrm{a} \\
10.0 \mathrm{a} \\
10.0 \mathrm{a}\end{array}$ & $\begin{array}{l}3.3 c \\
3.7 b c \\
3.7 b c \\
4.0 a b c\end{array}$ & $\begin{array}{l}7.0 \mathrm{~b} \\
8.0 \mathrm{a} \\
7.0 \mathrm{~b} \\
7.0 \mathrm{~b}\end{array}$ & $\begin{array}{l}7.8 \mathrm{~b} \\
8.8 \mathrm{ab} \\
7.7 \mathrm{~b} \\
7.8 \mathrm{~b}\end{array}$ \\
\hline Early head & $\begin{array}{l}\text { High } \\
\text { High } \\
\text { Low } \\
\text { Low }\end{array}$ & $\begin{array}{l}\text { High } \\
\text { Low } \\
\text { High } \\
\text { Low }\end{array}$ & $\begin{array}{l}10.0 \mathrm{a} \\
10.0 \mathrm{a} \\
10.0 \mathrm{a} \\
10.0 \mathrm{a}\end{array}$ & $\begin{array}{l}3.7 \mathrm{bc} \\
4.3 \mathrm{abc} \\
4.0 \mathrm{abc} \\
4.3 \mathrm{abc}\end{array}$ & $\begin{array}{l}7.0 \mathrm{~b} \\
7.0 \mathrm{~b} \\
7.0 \mathrm{~b} \\
7.0 \mathrm{~b}\end{array}$ & $\begin{array}{l}8.2 a b \\
9.0 a \\
8.7 a b \\
7.8 b\end{array}$ \\
\hline Early bloom & $\begin{array}{l}\text { High } \\
\text { High } \\
\text { Low } \\
\text { Low }\end{array}$ & $\begin{array}{l}\text { High } \\
\text { Low } \\
\text { High } \\
\text { Low }\end{array}$ & $\begin{array}{l}10.0 \mathrm{a} \\
10.0 \mathrm{a} \\
10.0 \mathrm{a} \\
10.0 \mathrm{a}\end{array}$ & $\begin{array}{l}5.3 a \\
4.7 a b \\
4.7 a b \\
3.7 b c\end{array}$ & $\begin{array}{l}8.0 \mathrm{a} \\
7.0 \mathrm{~b} \\
7.0 \mathrm{~b} \\
7.0 \mathrm{~b}\end{array}$ & $\begin{array}{l}9.2 \mathrm{a} \\
9.2 \mathrm{a} \\
9.2 \mathrm{a} \\
7.8 \mathrm{~b}\end{array}$ \\
\hline Past bloom & $\begin{array}{l}\text { High } \\
\text { High } \\
\text { Low } \\
\text { Low }\end{array}$ & $\begin{array}{l}\text { High } \\
\text { Low } \\
\text { High } \\
\text { Low }\end{array}$ & $\begin{array}{l}10.0 \mathrm{a} \\
10.0 \mathrm{a} \\
10.0 \mathrm{a} \\
10.0 \mathrm{a}\end{array}$ & $\begin{array}{l}4.7 a b \\
4.7 a b \\
4.0 a b c \\
3.0 c\end{array}$ & $\begin{array}{l}8.0 \mathrm{a} \\
8.0 \mathrm{a} \\
7.0 \mathrm{~b} \\
7.0 \mathrm{~b}\end{array}$ & $\begin{array}{l}9.3 \mathrm{a} \\
9.3 \mathrm{a} \\
9.0 \mathrm{a} \\
8.2 \mathrm{ab}\end{array}$ \\
\hline Averages: & & & & & & \\
\hline $\begin{array}{l}\text { PJ } \\
\mathrm{EH} \\
\mathrm{EB} \\
\mathrm{PB}\end{array}$ & & & $\begin{array}{l}10.0 \mathrm{r} \\
10.0 \mathrm{r} \\
10.0 \mathrm{r} \\
10.0 \mathrm{r}\end{array}$ & $\begin{array}{l}3.7 \mathrm{~s} \\
4.1 \mathrm{rs} \\
4.6 \mathrm{r} \\
4.1 \mathrm{rs}\end{array}$ & $\begin{array}{l}7.2 \mathrm{r} \\
7.0 \mathrm{r} \\
7.2 \mathrm{r} \\
7.5 \mathrm{r}\end{array}$ & $\begin{array}{l}8.0 \mathrm{t} \\
8.4 \mathrm{st} \\
8.9 \mathrm{rs} \\
9.0 \mathrm{r}\end{array}$ \\
\hline & $\begin{array}{l}\text { High } \\
\text { Low }\end{array}$ & & $\begin{array}{l}10.0 \mathrm{w} \\
10.0 \mathrm{w}\end{array}$ & $\begin{array}{l}4.2 \mathrm{w} \\
4.0 \mathrm{w}\end{array}$ & $\begin{array}{l}7.5 \mathrm{w} \\
7.0 \mathrm{x}\end{array}$ & $\begin{array}{l}8.8 \mathrm{w} \\
8.3 \mathrm{x}\end{array}$ \\
\hline & & $\begin{array}{l}\text { High } \\
\text { Low }\end{array}$ & $\begin{array}{l}10.0 \mathrm{y} \\
10.0 \mathrm{y}\end{array}$ & $\begin{array}{l}4.3 \mathrm{y} \\
3.9 \mathrm{y}\end{array}$ & $\begin{array}{l}7.2 \mathrm{y} \\
7.2 \mathrm{y}\end{array}$ & $\begin{array}{l}8.6 \mathrm{y} \\
8.5 \mathrm{y}\end{array}$ \\
\hline C.V. $\%$ & & & & 17.9 & 7.0 & 6.7 \\
\hline
\end{tabular}

${ }^{2}$ Values having the same letter are from the same statistical population at the 5 per cent level of significance. Comparisons may be made within each column, with each group of average values considered separately.

when the first harvest date was delayed. The importance of these observations is illustrated in Figure 6. While dry matter yield increased during maturation of the first crop, no additional increase in amount of digestible dry matter occurred after the heading stage.

Per cent digestibility of protein or dry mat- ter (Table 13) was similar in all aftermaths regardless of the stage of maturity at first harvest. Both the digestible protein and digestible dry matter content indicate that the aftermath forage was comparable to first cut forage harvested between the pre-joint and early head stages.

\section{DISCUSSION}

Data from these studies clearly demonstrate that under favorable conditions reed canarygrass has the potential to produce at least six tons of dry matter per acre. The amount of forage produced, however, will be markedly influenced by nitrogen fertilization, precipitation, 
TABLE 11

First Cutting Yields of Dry Matter Produced by Reed Canarygrass Following Three Harvest Years

Previous Treatment

Stage at First Harvest $\quad$ N Aftermath Cut
Pre-joint

Early head

Early bloom

Past bloom

Averages:

PJ
EH
EB
PB

C.V. $\%$
Early bloom

\section{High}

\section{High}

Low

Low

\section{High}

High

Low

Low

High

High

Low

Low

\section{High}

High

Low

Low be made within each column, with each group of average values considered separately.

1.16
1.08
1.19
1.13
1.36
0.96
1.16
1.11

1.11
$2.88 \mathrm{r}$

$2.96 \mathrm{r}$

$3.27 \mathrm{r}$

$2.62 \mathrm{r}$

High

Low

High

Low

\section{$3.10 \mathrm{w}$}

$2.76 \mathrm{w}$

$2.94 \mathrm{y}$
$2.93 \mathrm{y}$

19.7
First Harvest 1963 (T/A)

Conn. N. Y. Pa. $\quad$ Md.

$\begin{array}{llll}1.50 & 2.35 \mathrm{a}^{1} & 1.32 \mathrm{c} & 0.71 \mathrm{abcd} \\ 1.19 & 3.36 \mathrm{a} & 1.25 \mathrm{~cd} & 0.95 \mathrm{a} \\ 0.94 & 2.67 \mathrm{a} & 0.55 \mathrm{fg} & 0.35 \mathrm{~d} \\ 1.01 & 3.15 \mathrm{a} & 0.48 \mathrm{~g} & 0.80 \mathrm{abc} \\ 1.13 & 3.09 \mathrm{a} & 1.13 \mathrm{de} & 0.65 \mathrm{abcd} \\ 1.40 & 2.98 \mathrm{a} & 1.29 \mathrm{~cd} & 0.88 \mathrm{ab} \\ 0.80 & 2.97 \mathrm{a} & 0.70 \mathrm{f} & 0.39 \mathrm{~d} \\ 0.96 & 2.79 \mathrm{a} & 0.62 \mathrm{fg} & 0.35 \mathrm{~d} \\ 1.55 & 3.52 \mathrm{a} & 2.08 \mathrm{ab} & 0.92 \mathrm{a} \\ 1.35 & 4.00 \mathrm{a} & 1.96 \mathrm{~b} & 0.86 \mathrm{ab} \\ 1.00 & 3.06 \mathrm{a} & 0.99 \mathrm{e} & 0.43 \mathrm{~cd} \\ 0.86 & 2.51 \mathrm{a} & 1.00 \mathrm{e} & 0.38 \mathrm{~d} \\ 1.49 & 3.12 \mathrm{a} & 1.99 \mathrm{~b} & 0.95 \mathrm{a} \\ 1.28 & 2.40 \mathrm{a} & 2.22 \mathrm{a} & 0.99 \mathrm{a} \\ 0.89 & 2.71 \mathrm{a} & 1.04 \mathrm{e} & 0.37 \mathrm{~d} \\ 0.86 & 2.24 \mathrm{a} & 1.07 \mathrm{e} & 0.50 \mathrm{bcd}\end{array}$

$1.20 \mathrm{~s}$

$0.70 \mathrm{r}$

$0.58 \mathrm{r}$

$0.65 \mathrm{r}$

$2.01 \mathrm{r}$

$0.70 \mathrm{r}$

$2.10 \mathrm{r}$

$0.86 \mathrm{w}$

$1.66 \mathrm{w}$

$0.45 \mathrm{x}$

$0.81 x$

$0.50 \mathrm{z}$

$0.72 \mathrm{y}$

$\begin{array}{ll}1.23 \mathrm{y} & 0.50 \mathrm{z} \\ 1.23 \mathrm{y} & 0.72 \mathrm{y}\end{array}$

19.1

30.3

and stage of growth at the first harvest and to a lesser degree by removing or retaining the growing point when harvesting the first aftermath crop. Total yields at New York were considerably higher than at Maryland, primarily because first harvest yields were larger at New York. This was undoubtedly related to the higher water content (moderate drainage) of the soil each spring at New York. Aftermath production in many instances was tripled with favorable cutting management and high rates of nitrogen fertilization. Sometimes the aftermath yields exceeded three tons of dry matter per acre. This finding becomes especially important when considering scarcity of summer pasture in the Northeast.

Although the stands of reed canarygrass were thinning at some locations by the end of the third harvest year, these stands were less affected than those of either timothy or bromegrass in adjacent plots receiving the same harvest management. One of the most important single factors in maintaining a productive, healthy, vigorous stand appeared to be an adequate supply of available nitrogen.

Responses of reed canarygrass to cutting at four different physiological growth stages at first harvest or to cutting the first aftermath at 
TABLE 12

Chemical Composition of Reed Canarygrass Forage

\begin{tabular}{|c|c|c|c|c|c|c|c|}
\hline \multirow{3}{*}{$\begin{array}{c}\text { Stage at } \\
\text { First } \\
\text { Harvest }\end{array}$} & \multirow[b]{3}{*}{$\mathbf{N}$} & \multirow[b]{3}{*}{ Year } & \multicolumn{4}{|c|}{ Connecticut } & \multirow{3}{*}{$\begin{array}{c}\text { Maryland } \\
\text { Protein }\end{array}$} \\
\hline & & & \multicolumn{4}{|c|}{ Component (per cent air dry) } & \\
\hline & & & NFE & Fiber & Fat & Protein & \\
\hline PJ & High & 1960 & 36.3 & 21.2 & 3.4 & 18.4 & 22.5 \\
\hline $\mathbf{M J}^{1}$ & & & 33.0 & 25.3 & 4.0 & 18.6 & \\
\hline $\mathrm{EH}$ & & & 37.4 & 30.6 & 3.8 & 11.8 & 16.8 \\
\hline $\mathrm{EB}$ & & & 39.2 & 29.0 & 3.8 & 10.8 & 12.6 \\
\hline $\mathrm{PB}$ & & & 44.1 & 30.7 & 3.5 & 9.1 & 10.8 \\
\hline PJ & Low & & 40.8 & 20.2 & 3.5 & 16.0 & 19.3 \\
\hline $\mathrm{EH}$ & & & 39.5 & 29.6 & 3.3 & 9.4 & 16.9 \\
\hline $\mathrm{EB}$ & & & 40.6 & 29.4 & 3.5 & 9.4 & 11.5 \\
\hline $\mathrm{PB}$ & & & 48.1 & 28.9 & 2.8 & 7.3 & 10.3 \\
\hline PJ & High & 1962 & 28.0 & 19.3 & 5.6 & 31.0 & 21.0 \\
\hline MJ & & & 32.4 & 22.1 & 4.1 & 25.5 & \\
\hline $\mathrm{EH}$ & & & 38.6 & 27.6 & 4.3 & 15.0 & 14.4 \\
\hline EB & & & 36.6 & 31.4 & 3.8 & 14.0 & 11.3 \\
\hline $\mathrm{PB}$ & & & 50.2 & 29.0 & 2.6 & 10.5 & 10.0 \\
\hline PJ & Low & & 38.0 & 13.7 & 5.9 & 26.8 & 17.5 \\
\hline $\mathrm{EH}$ & & & 38.0 & 19.8 & 4.4 & 22.5 & 13.0 \\
\hline EB & & & 46.2 & 27.5 & 3.2 & 10.0 & 10.9 \\
\hline PB & & & 50.5 & 27.2 & 2.6 & 7.5 & 9.4 \\
\hline
\end{tabular}

'Mid-joint stage

TABLE 13

Digestibility of Reed Canarygrass Forage*

\begin{tabular}{|c|c|c|c|c|c|c|c|}
\hline \multirow{3}{*}{$\begin{array}{l}\text { Stage at } \\
\text { First } \\
\text { Harvest }\end{array}$} & \multicolumn{7}{|c|}{ Digestible (In vitro) Constituents } \\
\hline & \multicolumn{4}{|c|}{ Connecticut (1962) } & \multicolumn{3}{|c|}{ Maryland (1962) } \\
\hline & \multicolumn{2}{|c|}{$\begin{array}{l}\text { Harvest } \\
\text { Schedule }\end{array}$} & \multirow{2}{*}{$\begin{array}{c}\text { Per Cent } \\
\text { Protein } \\
26.7\end{array}$} & \multirow{2}{*}{$\begin{array}{c}\begin{array}{c}\text { Per Cent } \\
\text { Dry Matter }\end{array} \\
86.1\end{array}$} & \multirow{2}{*}{$\begin{array}{c}\begin{array}{c}\text { Harvest } \\
\text { Schedule }\end{array} \\
5-6\end{array}$} & \multirow{2}{*}{$\begin{array}{c}\begin{array}{c}\text { Per Cent } \\
\text { Protein }\end{array} \\
19.3\end{array}$} & \multirow{2}{*}{$\begin{array}{c}\begin{array}{c}\text { Per Cent } \\
\text { Dry Matter }\end{array} \\
78.8\end{array}$} \\
\hline \multirow{3}{*}{ Pre-joint } & 1st Harvest & $5-11$ & & & & & \\
\hline & 2nd Harvest & $5-29$ & 19.9 & 79.4 & $6-15$ & 18.2 & 72.8 \\
\hline & 3rd Harvest & $7-2$ & 19.4 & 72.4 & $7-24$ & 21.4 & 76.4 \\
\hline \multirow[t]{2}{*}{ Early head } & 1st Harvest & $6-1$ & 10.7 & 72.2 & $5-25$ & 12.3 & 72.0 \\
\hline & 2nd Harvest & $6-27$ & 18.4 & 77.2 & $6-15$ & 24.2 & 80.1 \\
\hline \multirow[t]{2}{*}{ Early bloom } & 1st Harvest & $6-7$ & 8.3 & 69.4 & $6-1$ & 10.8 & 70.5 \\
\hline & 2nd Harvest & $7-5$ & 19.6 & 75.4 & $7-2$ & 21.6 & 74.7 \\
\hline \multirow[t]{2}{*}{ Past bloom } & 1st Harvest & $6-22$ & 6.6 & 59.4 & $6-15$ & 6.8 & 60.3 \\
\hline & 2nd Harvest & $8-8$ & 15.3 & 67.4 & $7-18$ & 20.9 & 72.2 \\
\hline
\end{tabular}

-Nitrogen was applied at 75 pounds per acre after each harvest. 


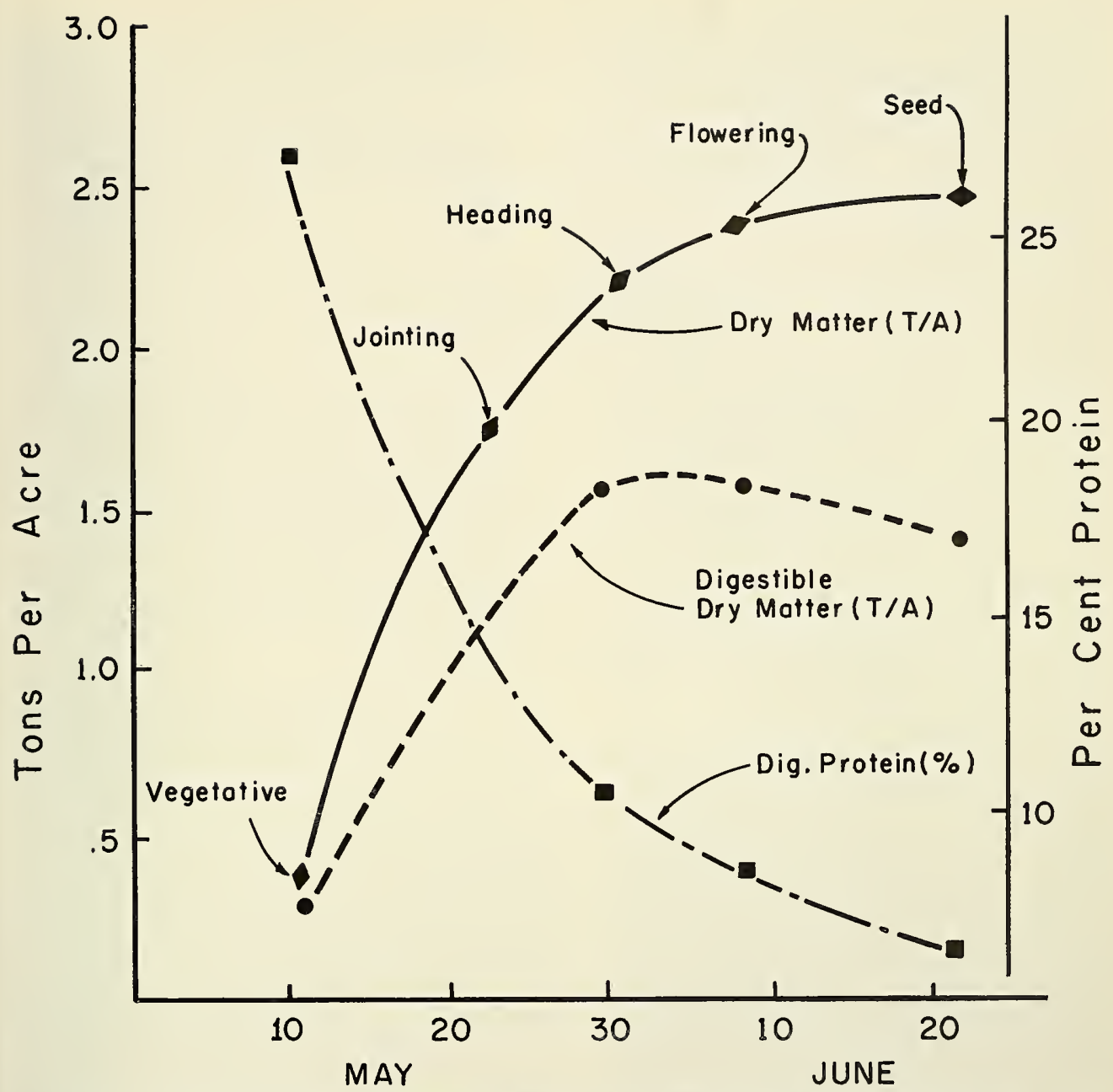

Figure 6. Trends of dry matter, digestible dry matter, and digestible protein for the spring growth of reed canarygrass in 1962 at Storrs, Connecticut. Nitrogen was applied at a rate of $75 \mathrm{lbs} / \mathrm{A}$ in early spring.

different heights were not in accordance with the concepts proposed by Teel (57) for bromegrass. Findings in this study show that a first cutting at different growth stages had some effect on season yields (Tables 2-4, Appendix Table 5) and seasonal distribution of yields, but certainly no consistent pattern was observed. Furthermore, production from these four cutting treatments did not appear to be closely associ- ated with reserves (as indicated by etiolated growth) which in turn were not clearly related to stand persistence. Removing or retaining the growing point at the time of the first aftermath harvest sometimes affected distribution of aftermath yields but had only a small effect on aftermath production. However, the frequency with which this treatment is imposed certainly could alter the response of reed canarygrass. Exami- 
nation of the growth potential following the differential height of cut suggests that continuous close cutting would result in lower reserve levels and ultimately less vigorous plants.

It was generally expected that recovery tests in the dark would provide an estimate of the reserve status closely associated with clipping and nitrogen treatments irrespective of moisture availability and thus show an important factor affecting growth after cutting. Studies with etiolated growth indicate that plant reserves in these studies were not the primary factor affecting regrowth. Chemical analyses for carbohydrate reserves or etiolated growth measurements of selected plant material indicate the relative amounts or concentrations of accumulated energy that is available for various metabolic activities of the plant. These measures integrate the effects of environment and management with the genetic capabilities of the plant to accumulate energy. The energy reserves of the plant may be used for the production of new leaves, stems, and roots or for respiration. Reserves accumulated by plants may not be reflected in total seasonal yields of dry matter, however, if an environmental factor such as moisture limits growth.

It was also evident that reserves, as measured by chemical analyses for carbohydrate content were much higher in plants which received the lower amounts of nitrogen in the field, whereas no such consistent pattern was observed in the etiolated growth measurements. The former technique estimates concentration of reserves while the latter technique estimates the reserve status per tiller. Thus, results obtained with these techniques could be affected differently by the size of the tillers present. In addition, nitrogenous reserves may have contributed significantly to the production of etiolated growth, thus accounting, in part, for this difference.

After the first harvest season, a relatively short period of time was required for reed canarygrass to pass from the early head stage to the early bloom stage of growth (time interval was longer for other grass species). The short time interval between the two growth stages was undesirable from the viewpoint of following metabolic, physiological, or nutritional changes associated with maturation.

Even though most of the reed canarygrass tillers appeared to be at a certain stage of development at the time of harvest, the plants at the four locations probably were not always comparable physiologically. For example, climatic differences in either fall or the following spring at these locations could (and did) greatly alter the utilization and/or replenishment of reserves. Such metabolic alterations would explain the variability observed in the growth potential measurements and in other responses. Furthermore, a stand of perennial grass consists of enormous numbers of short-lived vegetative units which may differ considerably from one another in degree of development and ability to withstand adversity. Therefore, the application of a so-called "uniform treatment," such as mowing at a specific height, elicits responses of still further diversity. It has become imperative that systems of management be developed which will successfully exploit yield potential of perennial grasses without sacrificing longevity or nutritional value. These systems must be based upon a more thorough understanding of structure and function. Studies designed to provide information on the relationships between growth of perennial grasses and their structure or physiological function are now being undertaken in the Northeast.

It appears that reed canarygrass possesses many agronomic characteristics that make it a desirable forage species for intensive management systems in the Northeast, and it should not be ignored in future plant breeding or nutritional investigations. These studies also indicated that the apparent quality of reed canarygrass forage can be improved by early harvesting and good fertilization practices. Although the nutritive value data collected are helpful in evaluating the management practices, another important consideration must be emphasized. The literature review pointed out that animal acceptance (intake) of reed canarygrass was often a limiting factor in animal studies. Bratzler's studies (12) with sheep showed that over a four-week period of harvesting, the dry matter digestibility and intake decreased approximately 18 to 20 per cent. Similarly, it would be expected that the first crop in our studies would become less acceptable as well as less digestible as time of first harvest was delayed. If the forage was intended to support animal productivity in contrast to mere maintenance, time of first harvest would be an important consideration.

Michigan studies $(59,60)$ pose a serious question with regard to the quality of reed canarygrass forage. It is not clear why similar nutritional deficiency symptoms have not been observed elsewhere. Also, most chemical determi- 
nations of plant constituents indicate that if cut at the proper stage of maturity, reed canarygrass should be as nutritious, if not more so, than other perennial grasses.

It is obvious that more information is needed concerning factors that affect animal con- sumption and utilization of reed canarygrass forage. It also appears necessary that plant morphologists and physiologists describe their experimental materials in terms that are recognizable and useful to persons who conduct experiments in animal nutrition.

\section{LITERATURE CITED}

1. Allinson, D. W., Schillinger, J. Jr., Thomas, J. W. and Tesar, M. B. In vitro techniques for evaluating the use of forage management practices. J. An. Sci. 24:907. 1965.

2. Alway, F. J. and Nesom, G. H. Protein content of reed canarygrass on peat soils. J. Agr. Res. 40:297-320, 1930.

3. Archibald, J. G., Barnes, H. D., Fenner, H. and Gersten, B. Digestibility of alfalfa hay and reed canarygrass hay measured by two procedures. J. Dairy Sci. 45:858-860. 1962.

4. Arny, A. C. and Hodgson, R. E. Reed canarygrass for meadows and pastures. Minnesota Agr. Ext. Special Bull. 137. 8 pp. 1932 (rev).

5. Arny, A. C., Hodgson, R. E. and Nesom, G. H. Reed canarygrass for meadows and pastures. Minnesota Agr. Exp. Sta. Bull. 263. 27 pp. 1930.

6. Association of Official Agricultural Chemists. Official and Tentative Methods of Analysis, 9th ed., Wash., D.C. 1960.

7. Baltensperger, A. A. and Kalton, R. R. Variability in reed canarygrass (Phalaris arundinacea L.). 1. Agronomic characters. Agron. J. 50:659-663. 1958.

8. Barnes, R. F., Mott, G. O., Plumlee, M. P. and Packett, L. V. In vivo and in vitro evaluations of Phalaris arundinacea $\mathrm{L}$. clones differing in palatability. Agronomy Abst. p. 107. 1963.

9. Barth, K. M., Vander Noot, G. W. and Cason, J. L. A comparison of the nutritive value of alfalfa hay with bromegrass and reed canarygrass hays at various levels of nitrogen fertilization. J. Nutr. 68:383-391. 1959.

10. Begg, John E. and Wright, Madison J. Relative effectiveness of top and basal leaves for the growth of vegetative shoots of reed canarygrass (Phalaris arundinacea L.). Crop Sci. 4:607-609. 1964.

11. Bird, J. N. Stage of cutting studies: I. Grasses. J. Am. Soc. Agron. 35-845-861. 1943.

12. Bratzler, J. W. Unpublished data. Pennsylvania Agr. Expt. Sta. Personal Communication. 1966.

13. Brown, J. A. M. Evaluation of certain morphological and chemical characteristics in relation to palatability in reed canarygrass (Phalaris arundinacea L.). Ph.D. Thesis. Purdue University. 1961.

14. Brown, J. A. M. and Pickett, R. C. Clonal evaluation in Phalaris arundinacea: I. Variation in palatability. Agronomy Abst. p. 45. 1960.

15. Carter, J. F. and Law, A. G. The effect of clipping upon the vegetative development of some perennial grasses. J. Am. Soc. Agron. 40:1084-1091. 1948.

16. Chalupa, W. V., Cason, J. L. and Baumgardt, B. R. Nutritive value of reed canarygrass as hay when grown with various nitrogen levels. J. Dairy Sci. 44:874-878. 1961.
17. Crozier, A. A. Forage plants and wheat. Michigan Expt. Sta. Bull. 141. 30 pp. 1897.

18. Davis, W. E. P. Effect of clipping at various heights on characteristics of regrowth in reed canarygrass (Phalaris arundinacea L.). Canadian J. Plant Sci. 40:452-456. 1960.

19. Decker, A. M. Midland bermudagrass, a new forage grass for Maryland. Maryland Agr. Expt. Sta. Bull. 465. 22 pp. 1959.

20. Dethier, B. E. and Vittum, M. T. The climate of the northeast: Growing degree days. New York State Agr. Expt. Sta., Geneva, N. Y., Bull. 801. 84 pp. 1963.

21. Duell, Robert W. Utilization of fertilizer by six pasture grasses. Agron. J. 52:277-279. 1960.

22. Ellett, IV. B. and Carrier, L. The effect of frequent clipping on total yield and composition of grasses. J. Am. Soc. Agron. 7:85-87. 1915.

23. Evans, M. IV. and Ely, J. E. Growth habits of reed canarygrass. J. Am. Soc. Agron. 33:1017-1027. 1941.

24. Feldt, W. Bericht uber die tatigkeit des mooramtes des lanwirtschaftskammer fur die provinz ostpreussen. Protokoll Sitzung Zent.-Moor-Komm. 85-125-144. 1926.

25. Feldt, W. Die arbeiten des mooramts der landwirtschaftskammer fur die provinz ostpreussen im jahre. 1926. Protokoll Sitzung Zent.-Moor-Komm. 87:89-108. 1927.

26. Flint, C. L. [Brief Account of the Natural History or Description of All the Useful Grasses Found in (Massachusetts) Fields and Pastures.] Sec. Massachusetts Bd. Agr. Ann. Rpt. 4:5-284. 1857.

27. Gernert, W. B. Native grass behavior as affected by periodic clipping. J. Am. Soc, Agron. 28:447-456, 1936.

28. Graber, L. F., Nelson, N. T., Luekel, W. A. and Albert, W. B. Organic food reserves in relation to the growth of alfalfa and other perennial herbaceons plants. Wisconsin Agr. Res. Bull. 80. 128 pp. 1927.

29. Harrington, J. D. and Washko, J. B. Forage and protein production of several pasture grasses as influenced by nitrogen fertilization. Pennsylvania Agr. Expt. Sta. Prog. Rept. 147. 8 pp. 1956.

30. Harrison, C. M. Effect of cutting and fertilizer applications on grass development. Plant Physiol. 6:669-684. 1931.

31. Heinze, P. H. and Murneek, A. E. Comparative accuracy and efficiency in determination of carbohydrates in plant material. Missouri Agr. Expt. Sta. Res. Bull, 314. 23 pp. 1940.

32. Hills, J. L. Feeding Tests of Milch Cows. Vermont Agr. Expt. Sta. Ann. Rept. 3:51-86. 1890.

33. Holden, E. D. and Albert, A. R. Reed canarygrass for Wisconsin lowlands. Wisconsin Agr. Ext. Circ. 264. 16 pp. 1933. 
34. Ingalls, J. R., Thomas, J. W., Benne, E. J. and Tesar, M. B. Comparative response of wether lambs to several cuttings of alfalfa, birdsfoot trefoil, bromegrass and reed canarygrass. J. An. Sci. 24:1159-1163. 1965.

35. Ingalls, J. R., Thomas, J. W' and Tesar, M. B. Comparison of responses to various forages by sheep, rabbits and heifers. J. An. Sci, 24:1165. 1965.

36. Jung. G. A., Lilly, B., Shih, S. C. and Reid, R. L. Studies with Sudangrass. I. Effect of growth stage and level of nitrogen fertilizer upon yield of dry matter; estimated digestibility of energy, dry matter and protein; amino acid composition; and prussic acid potential. Agron. J. 56:533537. 1964.

37. McRary, Willard L. and Slattery, M. C. The colorimetric determination of fructosan in plant material. J. Biol, Chem. 157:161-167. 1945.

38. Northeast Regional Publication 19. The evaluation of for. age crops varieties and strains for use and adaptation in the Northeast. New Jersey Agr. Expt. Sta. Bull. 777. 1954.

39. Northeast Regional Publication 43. Forage climates in the Northeast. Pennsylvania Agr. Expt. Sta. Bull. 653. 1959.

40. Northeast Regional Publication. Cutting management of alfalfa and ladino clover in the Northeast. Rhode Island Agr. Expt. Sta. Bull. 356. 1960.

41. Northeast Regional Publication 41. Band and Broadcast seeding of alfalfa-bromegrass in the Northeast. Maryland Agr. Expt. Sta. Bull. A-108. 1960.

42. Northeast Regional Publication 42. Seedling management of grass-legume associations in the Northeast. New Jersey Agr. Expt. Sta. Bull. 804. 1963.

43. O'Donovan, P. B. Ad libitum intake and digestibility of forages by lambs as related to soluble and structural components. Ph.D. Thesis, Purdue University. 1964

44. Okajima, Hideo and Smith, Dale. Available carbohydrate fractions in the stem bases and seed of timothy, smooth bromegrass, and several other northern grasses. Crop Sci. 4:317-320. 1964 .

45. Phillips, T. G., Sullivan, J. T., Loughlin, M. E. and Sprague, V. G. Chemical composition of some forage grasses. 1. Changes with plant maturity. Agron. J. 46:361369. 1954.

46. Piper, C. V. Forage Plants and Their Culture. Macmillan Co., N. Y. Rev. Ed. 671 pp. 1924.

47. Piper, C. V. Cultivated Grasses of Secondary Importance. U. S. Dept. Agr. Bull. 1433. 43 pp. 1925.

48. Pritchard, G. 1., Folkins, L. P. and Pigden, W. J. The in vitro digestibility of whole grasses and their parts at progressive stages of maturity. Canadian J. Plant Sci. 43: 79-87. 1963.

49. Ramage, C. H., Eby, C., Mather, R. E. and Purvis, E. R.
Yield and chemical composition of grasses tertilized heavily with nitrogen. Agron. J. 50:59-62. 1958.

50. Roe, Joseph H. A colorimetric method for the determination of fructose in blood and urine. J. Biol. Chem. 107:1522. 1934.

51. Roe, R. and Mottershead, B. E. Palatability of Phalaris arundinacea L. Nature. 193:255-256. 1962.

52. Schoth, H. A. Reed canarygrass. U.S.D.A. Farmers' Bull. 1602. 10 pp. 1929.

53. Sprague, V. G. and Sullivan, J. T. Reserve carbohydrates in orchardgrass clipped periodically. Plant Physiol. 25:92102. 1950

54. Sprague, V. G., Carlson, G. E. and Motter, G. A. Jr. Regrowth of grasses in darkness indicates relative energy accumulation. Agron. Abst. p. 87. 1962.

55. Storer, F. H. Chemical composition of blue joint-grass (Calamagrostis canadensis), as contrasted with that of reed canarygrass (Phalaris arundinacea). Bull. Bussey Inst. 2:130-136. 1900 .

56. Sullivan, J. T. and Sprague, V. G. Reserve carbohydrates in orchardgrass cut for hay. Plant Physiol. 28:304-313. 1953.

57. Teel, M. R. The physiological age of bromegrass (Bromus inermis Leyss.) as is affects growth rate following defoliation. Ph.D. Thesis, Purdue University, 1956. Diss. Abs. 16:844. 1956

58. Thomas, J. W., Gorrill, A. D. L., Blank, G. N. and Tesar, M. B. Acceptability of alfalfa, bromegrass and canarygrass by sheep and their performance. J. An. Sci. 24:911. 1965.

59. Tan Arsdell, WV. J., Branaman, G. A., Harrison, G. M. and Davis, J. F. Pasture results with steers on reed canarygrass. Michigan Agr. Expt. Sta. Quart. Bull. 37:125-131. 1954.

60. Vary, K. A., Davis, J. F. and Harrison, C. M. Farmers' experiences with reed canarygrass. Michigan Agr. Expt. Sta. Quart. Bull. 33:34-43. 1950.

61. Vose, P. B. The agronomic potentialities and problems of the canarygrasses, Phalaris arundinacea $L$. and Phalaris tuberosa L. Herb. Abs. 29:77-83. 1959.

62. Wagner, R. E. Effects of differential clipping on growth and development of seedling grasses and legumes. Agron. J. 44:578-584. 1952 .

63. Weinmann, H. Determination of total available carbohydrates in plants. Plant Physiol. 22:279-290. 1947.

64. Wilkins, F. S, and Hughes, H. D. Agronomic trials of reed canarygrass. J. Am. Soc. Agron. 24:18-28. 1932.

65. Molf, D. D. and Savos, M. G. Observations of frit fly damage to reed canarygrass. F.A.O. Plant Protection 13. 14-16. 1965. 
Appendix 
TABLE 1

Horvest Schedules

\begin{tabular}{|c|c|c|c|c|c|c|c|c|}
\hline \multirow[b]{2}{*}{ State } & \multirow{2}{*}{$\begin{array}{c}\text { Stage at } \\
\text { First Harvest }\end{array}$} & \multicolumn{4}{|c|}{ Harvest Number } & \multirow[b]{2}{*}{ 5th } & \multirow[b]{2}{*}{6 th } & \multirow{2}{*}{$\begin{array}{c}\text { Total } \\
\text { Harvests }\end{array}$} \\
\hline & & $1 \mathrm{st}$ & $2 n d$ & 3rd & 4 th & & & \\
\hline \multicolumn{9}{|c|}{1960} \\
\hline \multirow[t]{4}{*}{ Connecticut } & Pre-joint & $5-1$ & $6-6$ & $7-6$ & $8-2$ & $9-15$ & $10-10$ & 6 \\
\hline & Early head & $5-26$ & $6-23$ & $7-27$ & $8-15$ & $10-10$ & & 5 \\
\hline & Early bloom & $6-9$ & $7-6$ & $8-2$ & $9-15$ & $10-10$ & & 5 \\
\hline & Past bloom & $6-23$ & $7-18$ & $9-31$ & $10-10$ & & & 4 \\
\hline \multirow[t]{4}{*}{ New York } & Pre-joint & $4-25$ & $6-2$ & $7-20$ & $10-2$ & $10-11$ & & 5 \\
\hline & Early head & $6-2$ & $6-28$ & $8-8$ & $9-8$ & $10-11$ & & 5 \\
\hline & Early bloom & $6-8$ & $7-8$ & $8-18$ & $10-11$ & & & 4 \\
\hline & Past bloom & $6-21$ & $7-25$ & $9-6$ & $10-11$ & & & 4 \\
\hline \multirow[t]{4}{*}{ Pennsylvania } & Pre-joint & $5-11$ & $6-17$ & $7-21$ & $10-13$ & & & 4 \\
\hline & Early head & $5-25$ & $6-28$ & $7-21$ & $10-13$ & & & 4 \\
\hline & Early bloom & $6-9$ & $7-11$ & 8-18 & $10-13$ & & & 4 \\
\hline & Past bloom & $6-27$ & $7-21$ & $8-26$ & $10-13$ & & & 4 \\
\hline \multirow[t]{4}{*}{ Maryland } & Pre-joint & $4-29$ & $6-17$ & $7-14$ & $8-23$ & $10-14$ & & 5 \\
\hline & Early head & $5-20$ & $6-24$ & $7-22$ & $8-31$ & $10-14$ & & 5 \\
\hline & Early bloom & $6-10$ & $7-8$ & $8-18$ & $10-14$ & & & 4 \\
\hline & Past bloom & $6-27$ & $7-22$ & $8-31$ & $10-14$ & & & 4 \\
\hline \multicolumn{9}{|c|}{1961} \\
\hline \multirow[t]{4}{*}{ Connecticut } & Pre-joint & $5-18$ & $6-16$ & $7-11$ & $8-14$ & $10-17$ & & 5 \\
\hline & Early head & $6-12$ & $7-11$ & $8-14$ & $9-20$ & $10-17$ & & 5 \\
\hline & Early bloom & $6-16$ & $7-11$ & $8-7$ & $9-12$ & $10-17$ & & 5 \\
\hline & Past bloom & $7-5$ & $7-28$ & $9-1$ & $10-17$ & & & 4 \\
\hline \multirow[t]{4}{*}{ New York } & Pre-joint & $4-17$ & $6-22$ & $7-25$ & $8-31$ & $10-10$ & & 5 \\
\hline & Early head & $6-12$ & $7-6$ & $8-15$ & $10-10$ & & & 4 \\
\hline & Early bloom & $6-15$ & $7-21$ & $8-23$ & $10-10$ & & & 4 \\
\hline & Past bloom & $6-29$ & $8-3$ & $9-8$ & $10-10$ & & & 4 \\
\hline \multirow[t]{4}{*}{ Pennsylvania } & Pre-joint & $5-11$ & $6-16$ & $7-28$ & $10-24$ & & & 4 \\
\hline & Early head & $6-12$ & $7-28$ & $8-28$ & $10-24$ & & & 4 \\
\hline & Early bloom & $6-13$ & $7-28$ & $8-28$ & $10-24$ & & & 4 \\
\hline & Past bloom & $6-20$ & $7-28$ & $8-28$ & $10-24$ & & & 4 \\
\hline \multirow[t]{4}{*}{ Maryland } & Pre-joint & $5-10$ & $6-12$ & $7-7$ & $8-21$ & $10-6$ & & 5 \\
\hline & Early head & $5-26$ & $6-19$ & $7-20$ & $8-29$ & $10-6$ & & 5 \\
\hline & Early bloom & $6-8$ & $6-29$ & $7-28$ & $8-29$ & $10-6$ & & 5 \\
\hline & Past bloom & $6-22$ & $7-13$ & $8-28$ & $10-6$ & & & 4 \\
\hline \multicolumn{9}{|c|}{1962} \\
\hline \multirow[t]{4}{*}{ Connecticut } & Pre-joint & $5-11$ & $5-29$ & $7-2$ & $8-15$ & $10-9$ & & 5 \\
\hline & Early head & $6-1$ & $6-27$ & $8-8$ & $10-9$ & & & 4 \\
\hline & Early bloom & $6-7$ & $7-5$ & $8-15$ & $10-9$ & & & 4 \\
\hline & Past bloom & $6-22$ & $8-8$ & $10-9$ & & & & 3 \\
\hline New York & Pre-joint & $5-10$ & $6-15$ & $8-15$ & $9-7$ & $10-11$ & & 5 \\
\hline & Early head & $5-26$ & $7-2$ & $8-15$ & $10-11$ & & & 4 \\
\hline & Early bloom & $6-4$ & $7-12$ & $8-15$ & $10-11$ & & & 4 \\
\hline & Past bloom & $6-20$ & $8-15$ & $10-11$ & & & & 3 \\
\hline Pennsylvania & Pre-joint & $5-9$ & $6-7$ & $10-10$ & & & & 3 \\
\hline & Early head & $6-6$ & $10-10$ & & & & & 2 \\
\hline & Early bloom & $6-18$ & $10-10$ & & & & & 2 \\
\hline & Past bloom & $6-25$ & $10-10$ & & & & & 2 \\
\hline Maryland & Pre-joint & $5-7$ & 6-15 & $7-24$ & $10-19$ & & & 4 \\
\hline & Early head & $5-25$ & $6-15$ & $7-24$ & $10-19$ & & & 4 \\
\hline & Early bloom & $6-1$ & $7-2$ & $8-7$ & $10-19$ & & & 4 \\
\hline & Past bloom & $6-15$ & $7-12$ & $8-7$ & $10-19$ & & & 4 \\
\hline
\end{tabular}




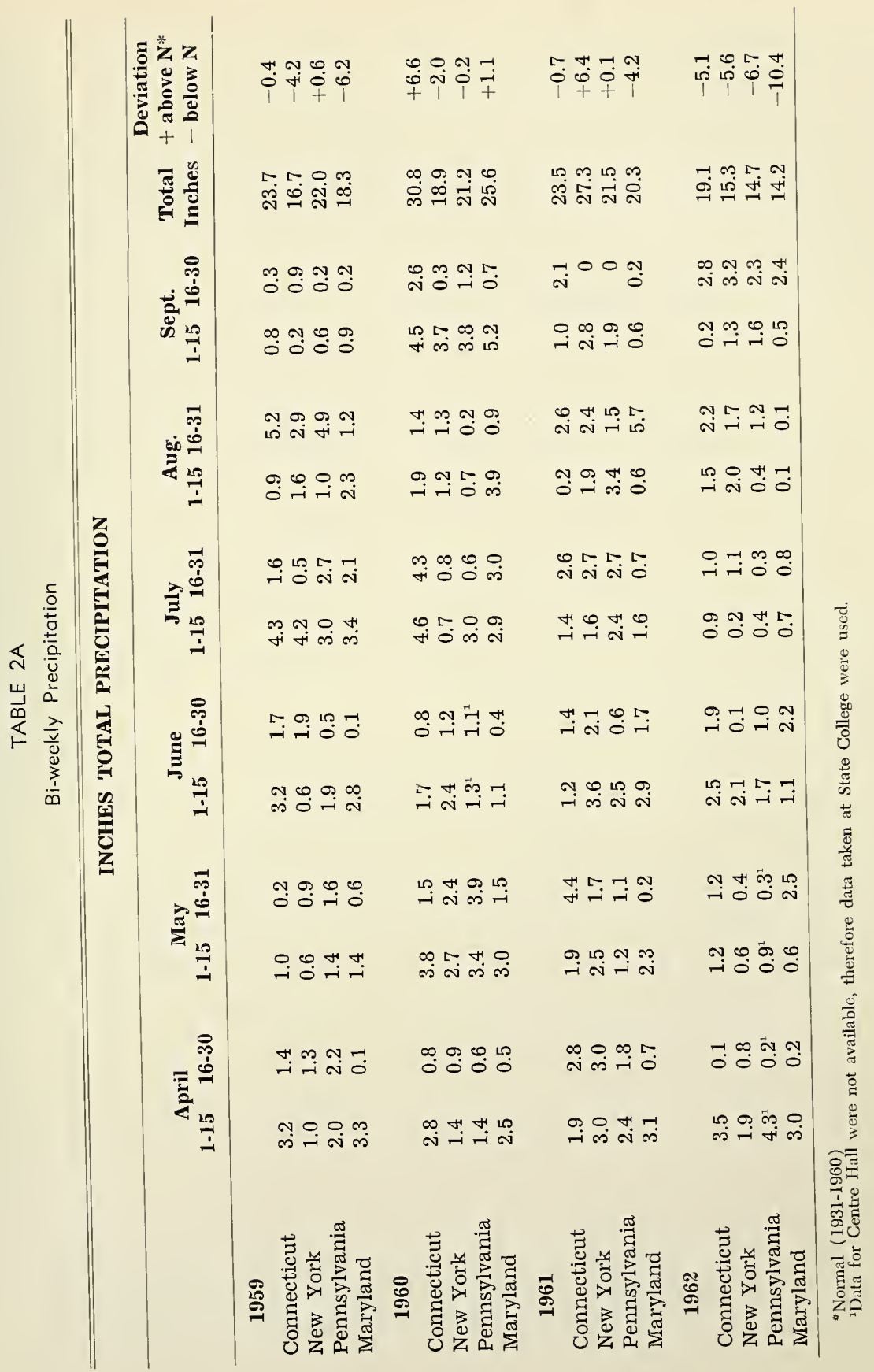




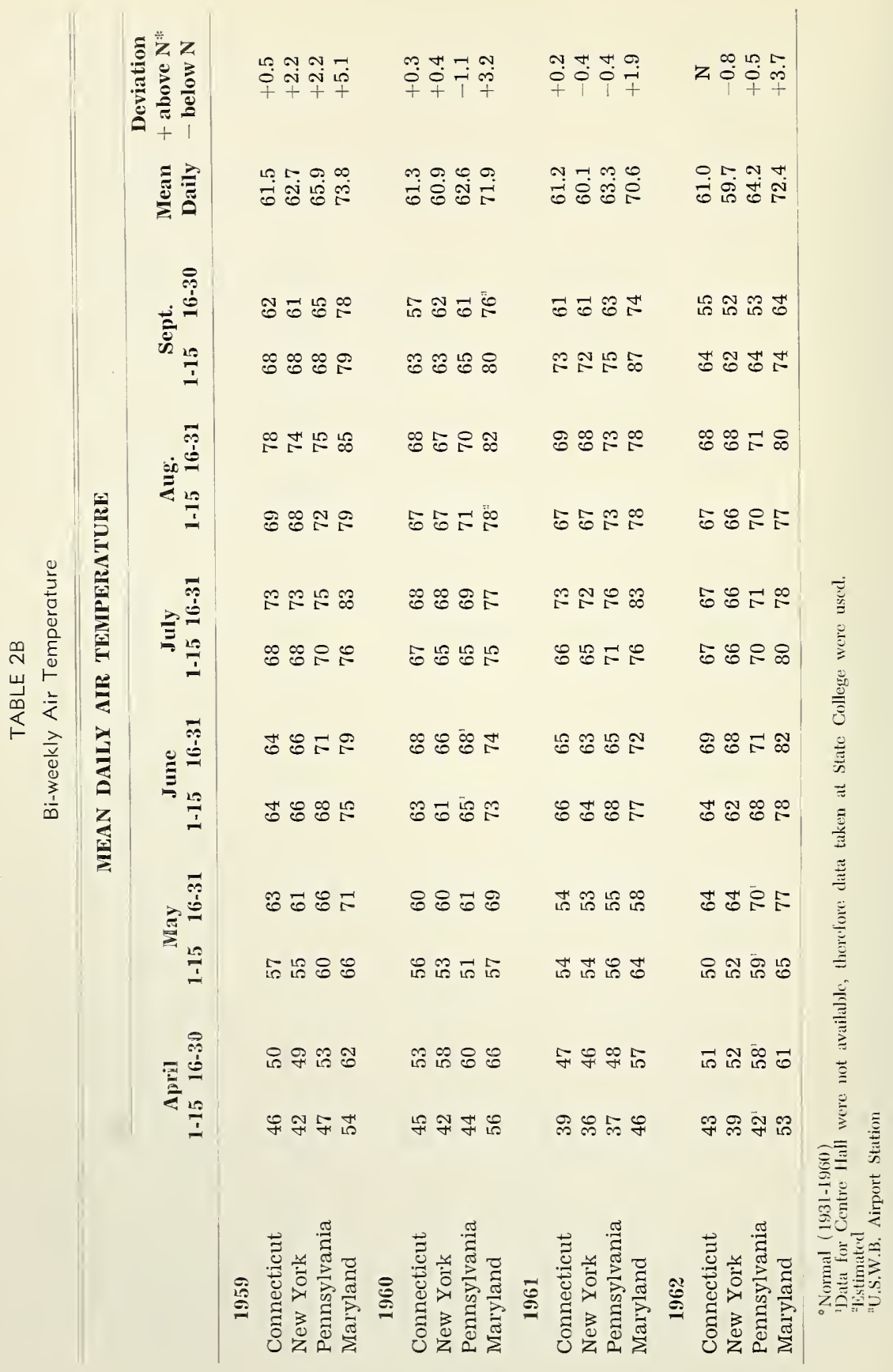


TABLE 2C

Descriptions of Weather Conditions (1960)

\section{Connecticut:}

Temperatures during March were below normal and growth through April was less than normal. A wet, warm May resulted in rapid growth and large crop yields. Generally, no serious moisture deficiencies occurred and the temperatures during May and June were above normal.

\section{New York:}

In the first year of production, May was wet; but the rest of the season was relatively cool and dry. The dryness was accentuated in the last quarter. Soil moisture blocks indicated very limited moisture availability from mid-July until September.

\section{Pennsylvania:}

Moisture was below normal in April, but May was a very wet month. A drought of seven weeks lasted from mid-July to the first week of September. Very little forage was produced during this period and the lack of moisture even masked the influence of nitrogen fertilization.

\section{Maryland:}

Temperatures in early spring were cool which delayed the start of most cool-season species. Precipitation was adequate during most of the summer except for the last half of June and early July when there was a drought coupled with high temperatures which resulted in little growth of forages. Excessive rainfall during May resulted in considerable lodging on the high nitrogen plots. Temperatures during much of the summer were normal or slightly below normal.

\section{Connecticut:}

The weather in spring was cold and wet with the last frost occurring May 31 . Total precipitation for the season was approximately normal and was evenly distributed except during August when only 0.23 inch was measured between August 1 and August 20. Temperatures were slightly above normal from June through August, but the September mean was a record $5.8^{\circ} \mathrm{F}$ above normal.

\section{New York:}

During the second year of production, precipitation was above average from April to August with an annual excess of seven inches. Temperatures were slightly cooler than normal. On the whole, it was an exceptionally favorable year for forage production.

\section{Pennsylvania:}

The 1961 growing season was quite favorable. Lack of adequate moisture was not a problem until mid-August, hence forage yields were well maintained through the major portion of the growing season. Moisture was deficient during the last half of August, September, and October which limited late aftermath production.

\section{Maryland:}

Weather conditions were generally favorable for forage growth up to mid-May. Rainfall was limited during late May, the first half of June, and most of July and first half of August. The latter part of August was wet, but September and October were again dry. As a result of the dry weather, fall forage growth was slow following the last harvest. However, favorable weather during most of November resulted in good growth before winter. 


\section{Connecticut:}

Temperatures in 1962 were normal in midseason and slightly above normal in spring and fall. A precipitation deficit (compared to normal) of 2.48 inches existed for the calendar year prior to April 1 and had increased to 6.25 inches by the end of September. The first killing frost occurred September 21. The growing season was 149 days as compared to 138 days in 1961.

Every month from July 1962 to November 1963 had below normal rainfall. Growth in early spring was good as long as the winter-stored moisture remained. Limited rain, however, reduced regrowth. The warm spring resulted in earlier than normal initiation of plant growth in 1963.

\section{New York:}

The third and last year of full production nad only two months warmer and two others wetter than normal, so it was both cool and dry. For the first time in the study, certain aftermath harvests were not made on schedule because growth was insufficient. The annual precipitation deficit exceeded six inches.

Preceding the common final harvest in 1963 , conditions were drier than normal except in May, and it was appreciably cooler than normal.

\section{Pennsylvania:}

The most severe drought in the history of weather records characterized the 1962 growing season. From March 1 to November 1, a rainfall deficit of 8.38 inches was recorded. This drought drastically reduced forage yields and curtailed the performance of reed canarygrass under the various management treatments.

\section{Maryland:}

In 1962, spring growth was delayed approximately two weeks because of low temperatures. Forage growth was good as a result of adequate rain and normal temperatures until mid-May when growth was slowed considerably because of low soil moisture coupled with above normal temperatures. Reed canarygrass plants exhibited extreme stress at this time with a large percentage of leaves actually killed. This was not noted on adjacent plots of bromegrass and orchardgrass. Forage growth was excellent during June as the result of rain in late May and early June. By the end of June, plants were again under moisture stress because of low rainfall and high temperatures. D r o u g h t conditions continued throughout most of July, August, and the first half of September. There was a seven inch rainfall deficit for July and August. Rainfall was good from October on, but cool temperatures resulted in slow forage growth. Because of this and the earlier drought, the final harvest was delayed until October 19.

$\mathrm{R}$ a i $\mathrm{n} \mathrm{fa} I \mathrm{l}$ and temperatures in the early spring and summer of 1963 were good for forage growth of cool season grasses. 
TABLE 3A

Analysis of Variance of Reed Canarygrass Yields Produced in the First Harvest Year (1960)

\begin{tabular}{|c|c|c|c|c|c|c|c|}
\hline State & Stage & Nitrogen & $\begin{array}{r}\text { Cutting } \\
\text { Height }\end{array}$ & SxN & SxCH & $\mathrm{NxCH}$ & SxNxCH \\
\hline \multicolumn{8}{|c|}{ Total Yield } \\
\hline Connecticut & $120.8 * *$ & $385.6 * *$ & 1.1 & $9.9^{* *}$ & 2.2 & $<1$ & 2.9 \\
\hline New York & $67.4 \% *$ & $720.0 \%$ & 2.5 & $5.4 * *$ & 2.4 & $<1$ & 1.4 \\
\hline Pennsylvania & 2.5 & $403.9 * *$ & $<1$ & $4.9^{* *}$ & 2.0 & 3.6 & 2.2 \\
\hline \multirow[t]{2}{*}{ Maryland } & $20.3^{* * *}$ & $491.1 * *$ & $<1$ & $12.9 \div *$ & 1.1 & $<1$ & $<1$ \\
\hline & \multicolumn{5}{|c|}{ Aftermath Yield } & & \\
\hline Connecticut $^{1}$ & & & & & & & \\
\hline New York & $69.0 * *$ & $593.0 * *$ & 1.8 & $5.3 * *$ & $4.0 *$ & $<1$ & $<1$ \\
\hline Pennsylvania & $87.0^{* * 3}$ & $483.4^{* *}$ & $<1$ & $10.9 *$ & $<1$ & 2.6 & 1.1 \\
\hline Maryland & $60.3^{* *}$ & $263.1 * *$ & $<1$ & $18.0 * *$ & 2.7 & 3.0 & 1.2 \\
\hline
\end{tabular}

.05 level of probability

$* .01$ level of probability

iData not available

TABLE 3B

Analysis of Voriance of Reed Canorygrass Yields Produced in the Second Harvest Year (1961)

\begin{tabular}{lccccccc}
\hline \multicolumn{1}{c}{ State } & Stage & Nitrogen & $\begin{array}{l}\text { Cutting } \\
\text { Height }\end{array}$ & SxN & SxCH & NxCH & SxNxCH \\
& & \multicolumn{7}{c}{ Total Yield } \\
Connecticut & $76.2^{* * *}$ & $640.9^{* *}$ & 2.2 & $7.7^{* *}$ & 1.2 & $<1$ & 2.3 \\
New York & $23.2^{* *}$ & $336.0^{* *}$ & 1.7 & $9.9^{* *}$ & 2.6 & $<1$ & $<1$ \\
Pennsylvania & $6.1^{* * *}$ & $506.5^{* *}$ & $<1$ & 1.6 & $<1$ & 2.5 & $<1$ \\
Maryland & $4.3^{* *}$ & $291.6^{* *}$ & $4.6^{*}$ & $5.4^{* *}$ & 1.2 & $<1$ & $<1$ \\
& & & Aftermath Yield & & & $<1$ \\
Connecticut & $97.1^{* *}$ & $213.5^{* *}$ & $<1$ & 2.2 & 1.3 & $<1$ & $<1$ \\
New York & $43.6^{* *}$ & $310.9^{* *}$ & $9.8^{* *}$ & $9.1^{* *}$ & 1.8 & $<1$ & 1.5 \\
Pennsylvania & $137.1^{* *}$ & $450.3^{* *}$ & $<1$ & $18.2^{* *}$ & $<1$ & 1.8 & 1.1 \\
Maryland & $34.8^{* *}$ & $311.8^{* *}$ & $4.5^{*}$ & $10.8^{* *}$ & $5.3^{* *}$ & $5.1^{*}$ & $<1$ \\
\hline
\end{tabular}

$\therefore .05$ level of probability

$* 01$ level of probability 
TABLE 3C

Analysis of Variance of Reed Canarygrass Yields Produced in the Third Harvest Year (1962)

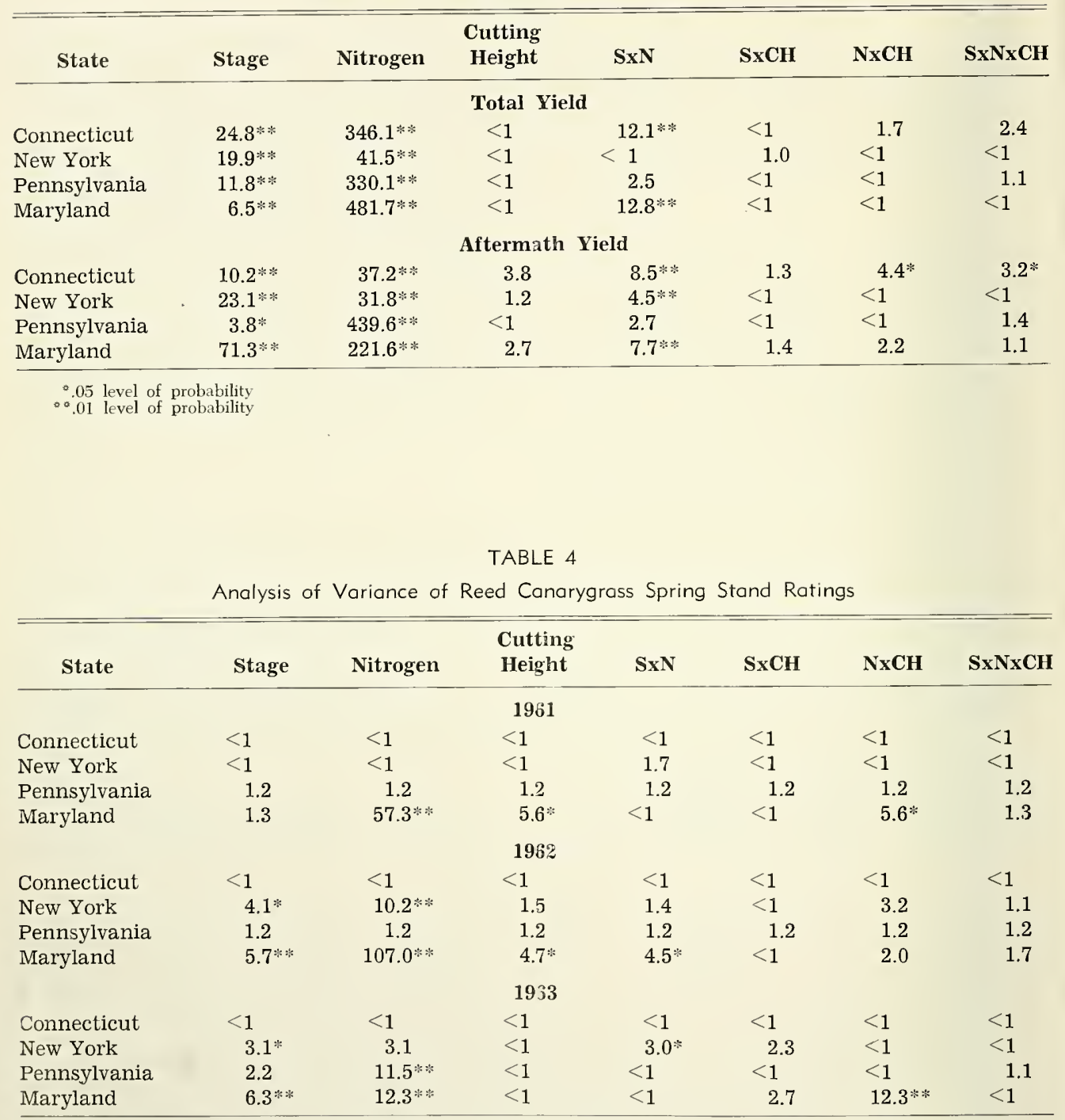

.05 level of probability

a. 01 level of probability 


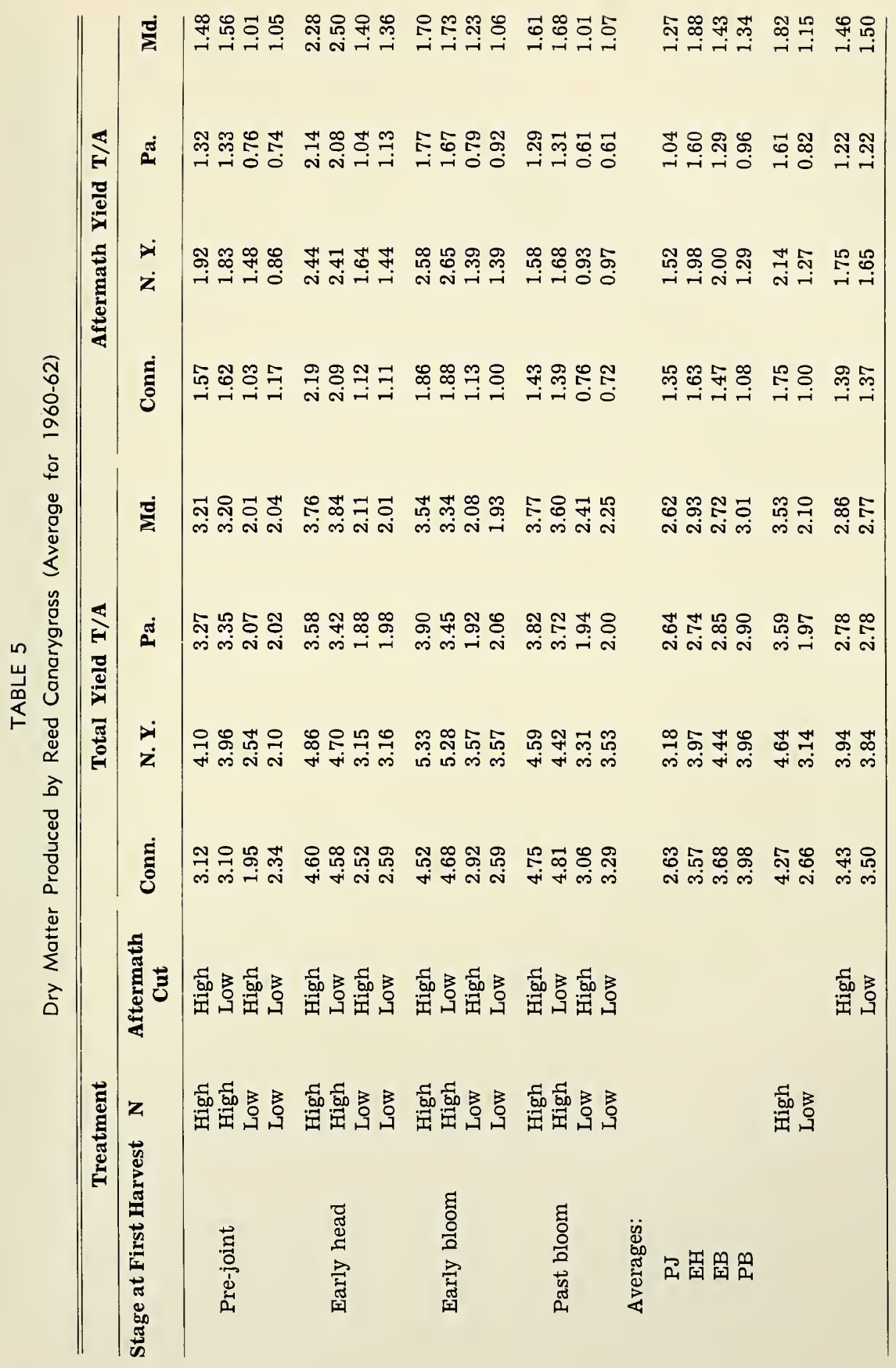






$$
=
$$



